\title{
Mobilita pracovní síly před a po vstupu ČR do EU
}

\author{
Marie Vavrejnová ${ }^{1}$
}

Úvod

Evropa až do počátku sedmdesátých let dvacátého století ve svých hlavních imigračních zemích, zejména Spolkové republice Německo a Francii, prováděla proimigrační politiku pro získávání cizích pracovníků. $\mathrm{V}$ každé z těchto dvou zemí pracovalo počátkem sedmdesátých let okolo dvou milionů cizích pracovníků a celkem v hlavních evropských zemích pracovalo přes 6 milionů cizích pracovníků. Hlavními zeměmi původu těchto pracovníků byly Itálie, Jugoslávie, Turecko, Španělsko, Portugalsko (v sestupném pořádku), tedy méně ekonomicky vyvinuté země Evropy. Z každé z těchto zemí pracovalo v zahraničí více než půl milionu pracovníků. Ekonomické důvody emigrace jsou zde zřejmé. Ze zemí východního bloku, z důvodů uzavření hranic, pracoval v západní Evropě významný počet pracovníků pouze z Polska - cca 180 tisíc osob. Současně ve světě pokračoval migrační proud do hlavních rozvinutých a tradičně imigrantských zemí. ${ }^{2}$

$\mathrm{S}$ růstem počtu zahraničních pracovníků se postupně v jednotlivých imigračních zemích Evropy počala zavádět restriktivní opatření na omezování imigrace. K Německu a Francii se přidalo Švédsko, Švýcarsko, Rakousko. Hlavní obrat v imigrační politice těchto zemí nastal v letech 1973 a 1974. Počaly dokonce podporovat finančně návrat cizích pracovníků do svých domovských zemí. Do roku 1980 skutečně počet cizích pracovníků poklesl v Rakousku a Francii o $16 \%$, ve Švýcarsku o $15 \%$ a ve Spolkové republice Německo o $8 \%$. Současně však rostl počet přistěhovalců z Afriky - z Alžírska, Maroka, Tuniska jako bývalých kolonií do Francie, s výhodou jazykových znalostí, a z Turecka do Spolkové republiky Německa. Tato imigrace znamenala přirůstek levnějšsí pracovní síly ve srovnání s cenou pracovní síly předchozích migračních proudů z méně rozvinutých zemí Evropy.

Předchozí vysoká imigrace do vyspělých západoevropských zemí, rychlý nárůst podílu cizích pracovníků a pokračující restriktivní opatření pomáhají porozumět současným obavám rozvinutých zemí západní Evropy z přistěhovalectví z nově přistupujících zemí k Evropské unii. Avšak restriktivní opatření nebyla uskutečňována pouze v západoevropských zemích. Z postkomunistických zemí se stalo zejména Mad’arskocílem emigrace čínské, poté co v roce 1988 podepsalo s Čínou smlouvu o bezvízovém styku. Liberální

1 Doc. Ing. Marie Vavrejnová, CSc., Institut integrace ČR do evropské a světové ekonomiky Fakulty mezinárodních vztahů Vysoké školy ekonomické v Praze.

2 Ve světě v průběhu druhé poloviny dvacátého století pokračovaly migrační proudy do hlavních imigračních zemí světa: USA, Kanady, Australie, na Nový Zéland. Hlavní regiony původu přistěhovalectví byly podle počtu emigrantů: z Mexika a Kuby do USA a Kanady, které mělo vzestupný trend, na druhém místě z Asie, opět hlavně do USA, s velmi vzestupným trendem, na třetím místě z Evropy do USA, Kanady, Australie, které však mělo snižující se trend. Přistěhovalectví z Afriky bylo ve srovnání s ostatními regiony řádově nižší, ale $\mathrm{s}$ rostoucím trendem a hlavně do USA. Výrazným trendem migrací z hlediska zemí původu byl snižující se podíl rozvinutých zemí a zvyšující se podíl zemí rozvojových. Tyto migrační proudy odrážely jak politický tak ekonomický vývoj ve světě. Statistika migračních proudů se teprve postupně zaváděla a sledovala pouze hrubě jejich hlavní směry, nebylo možné přesně od sebe oddělit hlavní důvody migrace. Avšak pokud bychom analyzovali podrobněji politický a ekonomický vývoj ve světě, souvislost s hlavními migračními proudy a jejich důvody by byly zřejmé. 
podnikatelské prostředí lákalo zejména do odvětví obchodu a pohostinství. Velký nárůst čínské komunity a s tím spojený rozvoj ilegálního přistěhovalectví a obchodování vedl již v roce 1991 k uplatnění projektu imigrační kontroly, který měl za následek snížení počtu čínské komunity o dvě třetiny, a byl zrušen bezvízový styk.

Základním mezníkem nových trendů migračních proudů v Evropě je pád totalitních režimů od počátku devadesátých let. Tato studie se věnuje vývoji migračních proudů v České republice od počátku devadesátých let do současné doby a pokouší se nastínit vývoj do budoucna, zejména z hlediska ekonomických motivací. Jinými aspekty migračních proudů (politickými, rodinnými) se zabývá pouze do té míry, do jaké doplňují a vymezují pohyb pracovní síly.

\section{Obecná východiska při zkoumání migrace obyvatelstva}

Obecně platnou ekonomickou motivací migrace obyvatelstva v moderní době jsou především mzdové diference - očekávání vyšší mzdy v cílové zemi. To platí i pro migrační proudy v evropských zemích, kde existují několikanásobné rozdíly ve mzdové úrovni. Praktickým projevem této motivace byl donedávna převažující výrazný migrační proud z méně ekonomicky vyvinutých zemí do vyvinutějších, který měl v evropském regionu konkrétní podobu přistěhovalectví z jižní Evropy do severnějších zemí (vysoké procento pracující imigrace z Itálie, Řecka, Portugalska atd. v Německu a Rakousku) a v současné době má podobu postupného posunu přistěhovalectví z východních zemí do západních. Předpokladem pro realizaci očekávání vyšších odměn za práci jsou ovšem volná pracovní místa. Tento předpoklad v podmínkách existující nezaměstnanosti (viz tabulka 2 př́lohy) je těžko splnitelný. Zaměstnanost roste pomalu, míra nezaměstnanosti se nesnižuje a emigrující lidé z postkomunistických zemí nejsou vždy žádoucí. Dochází k diferenciaci poptávky po pracovní síle: na jedné straně roste poptávka po kvalifikované pracovní síle, lidském kapitálu, jehož tvorba je drahá a v postkomunistických zemích nedoceněná, na druhé straně nacházejí v bohatších zemích pracovní uplatnění lidé v nekvalifikovaných nebo obtížných profesích, které místní obyvatelstvo není již ochotno vykonávat. Př́kladů bychom našli mnoho: od uklízečských povolání vykonávaných v západních zemích pracovníky z afrického kontinentu až po hornické práce vykonávané v Ceské republice polskými pracovníky. $\mathrm{K}$ motivaci vyšší pracovní odměny v podmínkách trvající nebo rostoucí nezaměstnanosti přistupuje motivace získat jakoukoliv práci, která umožní přežít. Tyto dva druhy motivací, to je vyšší mzda a možnost najít práci vůbec, se prolínají.

Dosud velké rozdíly ve mzdách ve východních a západních zemích Evropy jsou využívány jak emigranty, tak jejich zaměstnavateli a jsou živnou půdou i pro nelegální pracovní poměry. Tato situace ovlivňuje trh práce $\mathrm{v}$ hostitelských zemích, i zemích původu pracovníků, a to jak negativně, tak pozitivně. Pro obě země je situace příznivá v případě, že emigrace snižuje nezaměstnanost $\mathrm{v}$ mateřské zemi odchodem pracovníkủ a pomáhá řešit nedostatek pracovní síly v hostující zemi. Př́íladem opět může být zaměstnávání polských horníků v ostravských dolech. Tato výhoda platí však pouze do určité míry. Nepoměr mezi vyšší mírou nezaměstnanosti na polské straně hranice (průměrná míra nezaměstnanosti v Polsku je kolem $18 \%$, ale v př́hraničních oblastech přes $27 \%$ ) než v českých regionech a neochota českých pracovníků vykonávat některé práce dosud dovoluje zaměstnávat část polských pracovníků, avšak po úplné liberalizaci trhu práce může značně vy̌̌ší míra nezaměstnanosti v polských př́ihraničních regionech přenášet problémy do českých regionů. Negativní působení je především v již zmíněné nelegální migraci a nelegální zaměstnanosti a ve zvyšování nezaměstnanosti v hostující zemi. Uvolnění pracovního trhu nemůže zcela 
odstranit v podmínkách nezaměstnanosti nelegální práci, pod hranicí minimální mzdy. Problematika je analogická jako dnes uvnitř země.

O emigraci však zdaleka nerozhoduje pouze výše mzdy a míra nezaměstnanosti. Emigrant musí kalkulovat, do jaké míry je pro něho ještě výhodné vzdát se pro vyšší mzdu nižších životních nákladů v domovské zemi, zda vyšší mzda dovolí nahradit stěhovací náklady, respektive dopravní náklady při dojiždění, dále možnost zaměstnání rodinného příslušníka, možnost hrazení nákladů na studium dětí atd. Proto také velká část emigrantů se vrací a obměňuje, jak ukáží data migrační bilance ČR v další části studie. A proto také především starší pracovní síla a živitelé rodin dávají přednost dojíždění za prací v sousedních zemích. Tato skutečnost se týká především př́íhraničních oblastí a vyvolává nutnost specielního zkoumání dopadu ,pendlerstvi“" na ekonomiku těchto oblastí. Mimořádnou roli dále hraje $\mathrm{v}$ rozhodování o migraci sociální systém $\mathrm{v}$ domácí zemi. Vysoké podpory v nezaměstnanosti nebudou motivovat nezaměstnané k emigraci. Právě tak vysoké minimální mzdy nebudou motivovat k rozhodnutí o emigraci nekvalifikovanou pracovní sílu. Na druhé straně vyšší sociální dávky v cílové zemi lákají skupiny emigrantů, kteří více než pracovní př́iležitosti hledají zvýšení životní úrovně získáním vyšších sociálních výhod. To zase zpětně vyvolává snížení těchto výhod pro imigranty (viz v současné době v Británii v souvislosti s rozšriřením EU).

Jsou ještě další faktory, které ovlivňují migrační zisky imigranta: jazykové znalosti, kontakty $s$ předešlými emigranty, kteří mohou pomoci najít práci, poskytnout bydlení (dobře známé případy v ČR u imigrantů z asijského kontinentu). Proto teorie operující pouze s dvěma faktory - mzdovým diferenciálem a nezaměstnaností - zdaleka nestačí na vysvětlení objemů a struktury migrace.

Role emigrace i imigrace není dosud dostatečně prozkoumána z hlediska dlouhodobého vlivu na ekonomický a sociální vývoj společnosti. Za jeden z výrazně pozitivních dopadů migrace je považováno $\mathrm{v}$ evropských podmínkách zastavení stárnutí společnosti. Skutečně, $v$ průměru je emigrantská komunita o několik let mladší než domácí pracovníci (v Čechách o 4 roky). To však je z hlediska delší časové perspektivy dvousečná zbraň. Jednak jak uvidíme $\mathrm{v}$ další části studie, záleží na poměru počtu přistěhovalých osob a počtu pracujících imigrantů. Větší rodiny znamenají z hlediska přítomné doby vyšší sociální podpory a úlevy, tudíž větší vydání státního rozpočtu. Jednak imigranti stárnou a získávají nároky na důchod. Mnozí emigranti nechávají rodiny doma a v důchodovém věku se vracejí, takže jejich děti populaci hostující země neomlazují a té zbývá pouze platit důchod do zahraničí. To se týká v ČR imigrantů ze Slovenska a Ukrajiny. Podobná situace je u části imigrace také v Holandsku a Svédsku. Proto zejména holandští ekonomové a sociologové se intenzivně zabývají otázkami vlivu imigrace na vývoj společnosti. Aby mohla být provedena seriózní analýza role imigrace, bylo by nutno analyzovat věkové složení imigrantů, průměrnou délku pobytu, jejich začleňování do domácí společnosti a rodin, provádět průzkum jejich záměrů z hlediska budoucnosti. To však stojí dosud před námi.

Rozhodování o migraci v minulosti záviselo převážně na samotném pracovníkovi, jeho odvaze podstoupit změny a nezbytná rizika. S růstem migračních proudů jak legálních, tak nelegálních se počal vytvářet široký okruh právních předpisů národních i mezinárodních, vytvářejících rámec pro vstup, pohyb a ochranu cizinců, práva azylového, na druhé straně předpisů o ochraně státních hranic a podmínek jejich překračování. ČR se $\mathrm{k}$ tomuto procesu vytváření právního rámce migrace obyvatelstva přidala. Nové zákonné předpisy a novely starých jdou ve směru harmonizace s právními předpisy EU. Zejména byl připraven harmonogram úkolů k zajištění připravenosti ČR $\mathrm{k}$ přistoupení $\mathrm{k}$ Schengenskému acquis (z roku 1985 a postupně novelizovanému) upravujícímu hraniční režim a zej- 
ména počítajícímu s postupným rušením hraničních kontrol. Tento okruh právních předpisů je dále prodlužován do sféry pracovně právní a sociální, zahrnuje i bilaterální předpisy a dohody týkající se zejména podmínek zaměstnávání cizinců, podmínek upravujících jejich důchodové nároky a nároky na sociální dávky obecně a vytváří se soubor předpisů pro řízenou migraci. Od Amsterodamské dohody z roku 1997 v souvislosti s obavami ze stárnutí evropské populace se EU začala zabývat př́ípravou společné imigrační politiky, která by měla být řízená a selektivní. Příprava společné migrační politiky se týká i České republiky a bude o ní pojednáno dále.

\section{Fakta a data migračních proudů České republiky}

Pojem migrace obyvatelstva se stal pro Českou republiku od počátku devadesátých let ve srovnání s předchozím režimem důležitým faktorem demografického, ekonomického a sociálního vývoje. Česká republika se změnila ze země s převažující emigrací v zemi s vysokými parametry jak emigrace, tak imigrace, jejíž podíl zejména v poslední době roste. (V průběhu období 1948-1989 emigrovalo z českých zemí okolo 450 tisíc obyvatel, na druhé straně byli přijati pracovníci z Kuby a zejména Vietnamu v počtu asi 100 000, kteří se stali základem pro pozdější vietnamskou komunitu). V současné době má ČR jako většina evropských zemí pozitivní migrační bilanci. Nicméně podíl cizinců na celkovém počtu obyvatel je nízký (okolo $2 \%$, viz tabulka 1 př́lohy) ve srovnání s ostatními evropskými zeměmi, zejména se starými členy EU. (Nejvyšší podíl cizích pracovníků mezi nimi vykazuje Rakousko - 9,4 \% a Německo - 8,9 \%; vynechávám dvě malé země s vysokým podílem pracovníků mezinárodních institucí - Belgii a Lucembursko, což nepatří do zkoumané problematiky.)

Počet imigrantů v průběhu devadesátých let i v dalších letech přesahoval počet emigrantů (s výjimkou roku $2000 \mathrm{v}$ důsledku př́isnější legislativy a rozdílné metodiky). V roce 2002 byla čistá imigrace nejvyšší a tento trend dále pokračuje. Imigrace poněkud brzdí snižování počtu obyvatelstva, nicméně ČR nepatří mezi země s vysokou imigrací a podíl cizinců $\mathrm{v}$ celkovém počtu obyvatelstva je dosud nízký. Nejvyšší přírůstky obyvatelstva v důsledku imigrace v posledních letech vykazuje Irsko, Španělsko a Portugalsko, z kandidátských zemí Slovinsko a dále Chorvatsko. Na druhé straně v Polsku, Estonsku, Litvě a Lotyšsku počet emigrantů přesahuje počet imigrantů.

2.1 Migrační bilance České republiky v roce 2002 podle hlavních zemí, počet osob, legální migrace:

\section{Celkový počet imigrantů}

44679

$\mathrm{Z}$ toho
13326

10742

5691

1679

987

836

\section{Celkový počet emigrantů}

32389

Z toho

Slovensko

Ukrajina

Vietnam

Rusko

Polsko

Německo

USA
14455

5778

1273

1912

1117

1087

536
Bilance

12290

$-1129$

4964

4418

544

562

$-100$

300 
Hlavní proud imigrantů přichází a vrací se do východních zemí (záporná bilance se Slovenskem je celkem nahodilá, $v$ jednotlivých letech $\mathrm{v}$ poslední době převládá počet imigrantů nad počtem emigrantů). Čísla ukazují, že většina cizinců pracuje v ČR dočasně, poté, co vydělají určitou sumu peněz, se vrací domů a přicházejí dalš́í. Avšak postupně se počet emigrantů ze zemí na východ od ČR zvyšuje a stávají se ve stále rostoucím počtu rezidenty. K 31. prosinci 2002 bylo v ČR 231,6 tisíc osob s povolením trvalého pobytu a pobytu nad 90 dní. Od roku 1992 se jejich počet zvýšil 4,6x. Z hlediska země původu největší počet tvoří Slováci, Ukrajinci, Vietnamci, Poláci. (Podrobně vývoj imigrace a jejich strukturu podle zemí původu viz Tabulka $3 \mathrm{v}$ př́loze).

Současně s růstem počtu imigrantů se v České republice mění důvody imigrace. Na počátku devadesátých let převažoval $v$ počtu imigrantů počet občanů vracejících se z emigrace, v posledních letech výrazně roste atraktivnost České republiky pro imigranty z východní Evropy a Vietnamu z ekonomických důvodů a ČR se mění pro cizince z tranzitní země v zemi rezidentskou. Postupně se také snižuje průměrný věk imigrantů a v poslední době je na úrovni průměrného věku emigrantů.

\subsection{Ilegální migrace}

Přesný počet ilegálních migrantů není zjistitelný, avšak postupně zdokonalovaná ochrana hranic zlepšuje jejich evidenci. O počtu zachycené ilegální migrace, jejích směrech a způsobu provedení informují tabulky $6-10 \mathrm{v}$ př́loze. $V$ průběhu devadesátých let se počet osob zadržených na hranici postupně snižuje. Daleko největší podíl nelegální migrace se týká hranice mezi ČR a SRN. Její rozsah se také postupně snižuje. Zůstává však poměrně stejný na hranici s Rakouskem a roste na hranici s Polskem. Velký podíl nelegálních migrantů byl zadržen orgány jiných států, viz tabulka 7. Tabulka 6 poskytuje důležitou informaci: počet cizinců, kteří překračují ilegálně hranici s Německem a Rakouskem, je řádově vyšší než počet cizincư, kteří do ČR vstupují. Jaké mohou být příčiny tak velkých rozdílů? Částečnou odpovědna tuto otázku dává tabulka 10, která však zachycuje pouze poslední dva roky. Jednou z prŕíčin je, že legálně vstupující osoby do ČR ji opouštějí nelegálně, při tom jde o pohyb z východu na západ. (Může zde být časový posun mezi příchodem do republiky a jejím opuštěním.) Další logický důvod je ilegální př́íchod do ČR i odchod z ČR (cizinci jsou zachyceni hraničními orgány až při opouštění republiky).

V souvislosti se vstupem ČR do EU přijala vláda ČR v roce 2003 př́ísnější pravidla pro znemožnění všech forem nelegální migrace. Především jde o zdokonalení ochrany hranic, současně však jsou zpracovávána pravidla pro legalizaci pobytu a práce dosavadních nelegálně př́itomných osob, pokud je to účelné a z hlediska trhu práce užitečné (podobná opatření jak známo vstupují v platnost i v USA).

\section{Rozsah a trendy české migrace za prací}

Hlavní proud legální emigrace z ČR směřuje především v současné době do Německa a Rakouska. Legální zaměstnání českých občanů v Německu a Rakousku, právě tak jako zaměstnání občanů těchto zemí v ČR, je uskutečňováno na základě bilaterálních dohod a má více forem:

- sezónní práce (v trvání tří měsíců v roce),

- smluvní práce, 
- vzájemné zaměstnávání občanů za účelem zdokonalování jazykových a odborných znalostí, a konečně

- pendlerství - zaměstnání s denními návraty domů.

Forma pendlerství byla jak známo velmi rozšîřena na počátku devadesátých let, nejvyššího počtu dosáhli pendleři v roce 1992 (přes německé hranice např. tehdy pendlovalo 12400 osob), postupně se počet pendlerů snižoval a v současné době je odhadován na 5000 osob. Převládající věk pendlerů je mezi 40-49 lety, přibližně jednu pětinu z nich tvoří ženy. Hlavní výhodou pendlerství jsou vyšší mzdy v Německu a Rakousku na jedné straně a nižši životní náklady v ČR na straně druhé. Např. hodinové mzdy v průmyslu (v paritě kupní síly, v roce 1996) byly v Německu 26,5 EUR, v Rakousku 24,6 EUR, v ČR pouze 6,17 EUR (rok 1995). V celé EU jsou průměrné mzdy 4krát vyšší než v ČR, životní náklady však jsou vyšší jen 2,5krát. Takže je výhodné vydělávat peníze v zahraničí a nakupovat, resp. bydlet v ČR. Na druhé straně jsou tyto výhody snižovány vyššími náklady na cestování a ztrátou času. Negativním rysem této formy zaměstnání (ale i všech forem práce v zahraničí) je velmi častá ochota přijmout práci pod úroveň vzdělání pracovníků. Tato ochota je nevýhodná ve skutečnosti pro obě strany: tito pracovníci mohou brát práci dělníkům na druhé straně hranice a tím způsobovat jejich vyšší nezaměstnanost. Např. v Rakousku v období 1990-1996 se zvýšil počet domácích zaměstnanců pouze o $1 \%$, zahraničních však o $38 \%$. Současně vzrostla nezaměstnanost domácích pracovníků o $29 \%$. Bylo nutno proto zavést nová pravidla a nové limity regulující imigraci. Na druhé straně docházelo k úniku kvalifikované pracovní síly z českého území.

Postupně se však snižuje nebo stagnuje počet pracovníků v zahraničí i u jiných forem zaměstnání, než je pendlerství. Důvody jsou na obou stranách. Jednak klesající zájem českých pracovníků o práci v zahraničí (žrejmě za daných podmínek byla již poptávka po práci v zahraničí z velké části uspokojena; napřs. stanovené kvóty pro zaměstnání z důvodů zdokonalení jazykových a profesních znalostí jsou naplňovány sotva na padesát procent), jednak snižující se počet udělovaných pracovních povolení ze strany hostujících zemí. Existuje ovšem ilegální práce, zejména u sezónních zaměstnání v zemědělství a stavebnictví. Počet těchto pracovníků se těžko odhaduje, avšak v důsledku př́ísnějších hraničních kontrol a větších sankcí pro zaměstnavatele klesá.

Jak se přibližoval termín rozšiřrení EU, počaly se zvyšovat obavy ze strany Německa a Rakouska z nové vlny imigrace. Pokud se týče ČR, jsou tyto obavy málo opodstatnělé. Podívejme se na skladbu zahraničních pracovníků v těchto dvou zemích podle jejich původu. Nejvyšší počet imigrantů pochází ze zemí bývalé Jugoslávie a Turecka. Z postkomunistických zemí významný podíl má pouze Polsko. Podíl českých občanů je velmi nízký, jak dokazují statistiky obou zemí (viz Statistické ročenky Německa (2001) a Rakouska (2003), část „Zaměstnanost“): 


\section{Postavení České republiky v pořadí deseti národností pracujících v Rakousku a Německu:}

\section{Rakousko - zaměstnaní cizinci podle národností, rok 2002}

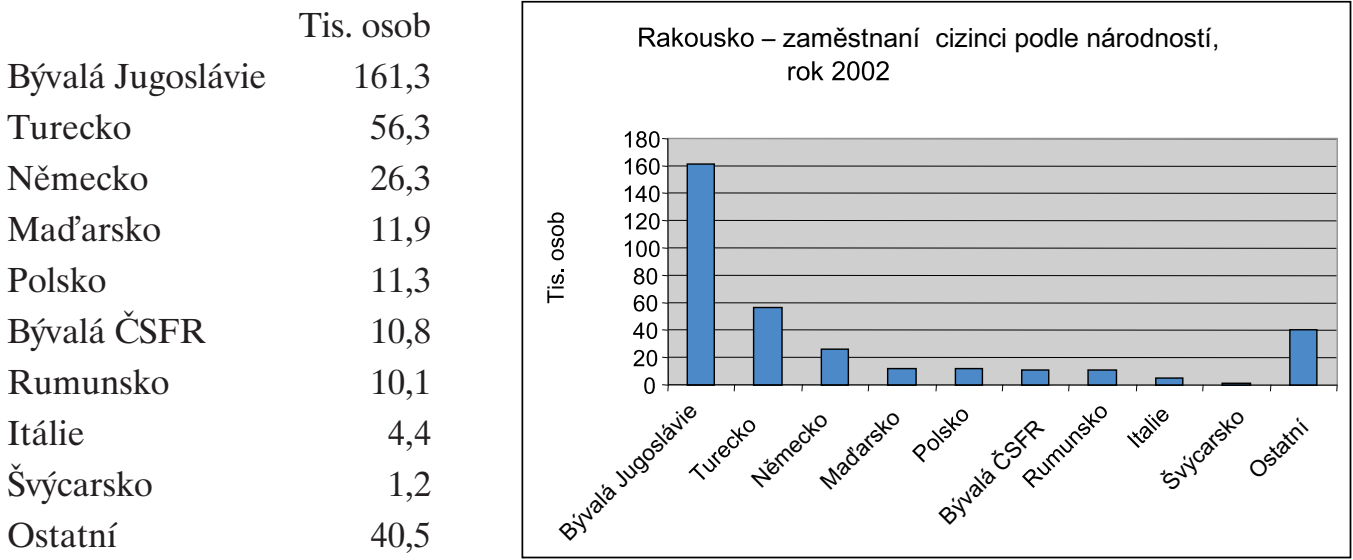

Německo - zaměstnaní cizinci podle národností, rok 2000

\begin{tabular}{|c|c|c|}
\hline Turecko & $\begin{array}{l}\text { osob } \\
556,4\end{array}$ & $\begin{array}{c}\text { Německo - zaměstnaní cizinci podle národností, } \\
\text { rok } 2000\end{array}$ \\
\hline Bývalá Jugoslávie & 283,1 & \\
\hline Itálie & 207,4 & $\begin{array}{l}600 \\
500\end{array}$ \\
\hline Řecko & 111,6 & $\begin{array}{ll}\text { 응 } & 400 \\
\text { ○ } & 300\end{array}$ \\
\hline Rakousko & 63,5 & $\stackrel{\dot{\infty}}{-} \quad 200$ \\
\hline Polsko & 59,0 & $\square, \square, \square, \square, \square, \square$ \\
\hline Portugalsko & 49,7 & 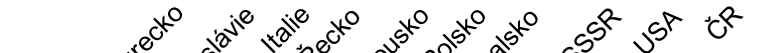 \\
\hline Bývalý SSSR & 24,1 & 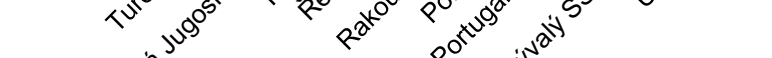 \\
\hline USA & 22,5 & \\
\hline$\check{C} \mathrm{R}$ & 13,2 & \\
\hline
\end{tabular}

Pramen dat: Rakouská statistická ročenka 2003, část „, Zaměstnanost“ (německy) Německá statistická ročenka 2001, část „Zaměstnanost“ (německy).

Poznámka: Rakouská statistika nesleduje v tomto případě zvlášt ČR a Slovensko.

Seriózní odpovědnha otázky spojené s emigrací českých občanů přináší obšírná studie Výzkumného ústavu práce a sociálních věcí, 2001 (viz http://www.vupsv.cz) obsahující výsledky průzkumu v českých a moravských regionech.

Zde jsou uvedena některá hlavní fakta vyplývající z tohoto průzkumu:

- Pokud se týče pendlerů, byl dotázán a zpracován vzorek 1197 občanů z pohraničních regionů za pomoci pracovníků úřadi̊ práce, celníků a zaměstnanců. Bylo zjištěno, že 5,1\% obyvatelstva nabyla zkušenosti s prací v Rakousku a 2,7\% v Německu. Se stálým pobytem mělo zkušenost 2,2\% občanu․

- Další vzorek více než 4,5 tisíc obyvatel ze všech regionů ČR ověril, že $86 \%$ respondentů nemá zájem o práci a pobyt v zahraničí. Z rodinných, psychologických a jiných di̊- 
vodi̊ preferují práci a bydlení doma. $Z$ obyvatel, kteř́ by uvažovali o emigraci, pouze 12 \% podniklo konkrétní kroky, aby získalo informace o emigraci. Mezi nimi však převládaji mladí lidé, kteři by chtěli studovat, cestovat, získávat v zahraničí zkušenosti. Většina z nich by preferovala dočasnou emigraci.

- Pořadí preferovaných zemí je: Německo, USA, Kanada, Rakousko.

Můžeme předpokládat, že krátká vzdálenost k sousedům nebude hrát podstatnou roli u zájemců o dlouhodobý pobyt při dnešních možnostech cestování. Významnou roli také hrají jazykové znalosti. Dnešní mladá generace dává přednost angličtině a anglicky mluvícím zemím. Proto dnes nacházíme rostoucí počet mladých lidí pracujících legálně i ilegálně v USA. To jsou také další důvody, proč česká veřejnost nesdílí německé a rakouské názory na budoucí rozsah emigrace do těchto zemí.

Konečné řešení problémů nežádoucí migrace bude spočívat v rostoucí ekonomické úrovni ČR a jejím přibližování k ekonomické úrovni zemí EU. Lze očekávat, že toto období bude značně dlouhé a mezi tím mohou nastat různé peripetie. Např. růst nezaměstnanosti v ČR v posledních letech může poněkud změnit rozhodování lidí a zjištění výše uvedené studie by tedy mohla být korigována. Celkové zaostávání Evropy v ekonomických výkonech a zaměstnanosti za USA (pro ilustraci je uveden vývoj HDP a zaměstnanosti v EU a USA) ${ }^{3}$ může podnítit mladé lidi k emigraci za oceán.

\section{Rozsah a trendy imigrace do ČR za prací}

Počet imigrantů v ČR od počátku devadesátých let postupně narůstal a Česká republika se změnila z emigrantské země v imigrantskou. Od roku 2000 se počet imigrantů poněkud snižoval vlivem změn v legislativě, které zpřísnily vstupní a pobytové podmínky. Od roku 2001 počet cizinců opět roste $\mathrm{v}$ důsledku novely zákona, která poněkud zmírnila některá ustanovení emigrantského zákona. Tato fakta jsou dokumentována následujícím vývojem počtu legálních imigrantů v ČR, držitelů povolení $\mathrm{k}$ pobytu:

\begin{tabular}{|l|c|c|c|c|r|r|c|}
\hline \multicolumn{1}{|c|}{ Legální imigrace } & $\mathbf{1 9 9 0}$ & \multicolumn{1}{c|}{$\mathbf{1 9 9 3}$} & \multicolumn{1}{c|}{$\mathbf{1 9 9 8}$} & \multicolumn{1}{c|}{$\mathbf{1 9 9 9}$} & \multicolumn{1}{c|}{$\mathbf{2 0 0 0}$} & \multicolumn{1}{c|}{$\mathbf{2 0 0 1}$} & \multicolumn{1}{c|}{$\mathbf{2 0 0 2}$} \\
\hline Počet cizinců & 34899 & 77668 & 220187 & 228862 & 200951 & 210794 & 231,600 \\
\hline Roční index & & 1,55 & 1,05 & 1,04 & 0,88 & 1,05 & 1,10 \\
\hline \% z celku & 0,33 & 0,75 & 2,11 & 2,19 & 1,93 & 2,02 & 2,27 \\
\hline $\begin{array}{l}\text { Obyvatelstvo ČR } \\
\text { celkem, tis, }\end{array}$ & 10575 & 10334 & 10290 & 10278 & 10227 & 10287 & 10201 \\
\hline
\end{tabular}

Zdroj: Cizinci v České republice, 2002, Český statistický úřad. Původní zdroj: Ředitelství cizinecké a pohraniční policie, Ministerstvo vnitra ČR.

Struktura zahraničních pracovníků v ČR, jak ji zobrazuje níže uvedený graf, odpovídá struktuře migrační bilance z roku 2002, uvedené na str. 3 této studie. Migrační trendy jsou v posledních letech značně stabilní a dlouhodobé. Jde o legální pracovníky, jak je zazname-

\begin{tabular}{lllrl}
\hline 3 Ilustrace: & \multicolumn{2}{c}{ Růst HDP } & \multicolumn{2}{c}{ Růst zaměstnanosti } \\
& EU & USA & EU & USA \\
$1993-1995$ & 1,62 & 3,15 & $-0,38$ & 2,05 \\
$1996-2002$ & 2,27 & 3,28 & 1,20 & 1,29 \\
\multicolumn{3}{l}{ Pramen: K. Aiginger,OSN, Jarní semináŕ 2004. }
\end{tabular}


nává oficiální statistika. Kromě toho se odhaduje, že v současné době pracuje v ČR cca 100 000 ilegálních pracovníků.

$\begin{array}{lr}\text { Slovensko } & 26,40 \% \\ \text { Ukrajina } & 25,50 \% \\ \text { Vietnam } & 11,70 \% \\ \text { Polsko } & 6,90 \% \\ \text { Rusko } & 5,50 \% \\ \text { Německo } & 2,20 \% \\ \text { Bulharsko } & 1,80 \% \\ \text { USA } & 1,50 \% \\ \text { Čína } & 1,40 \% \\ \text { Srbsko a Černá Hora } & 1,40 \% \\ \text { Ostatní } & 15,70 \%\end{array}$

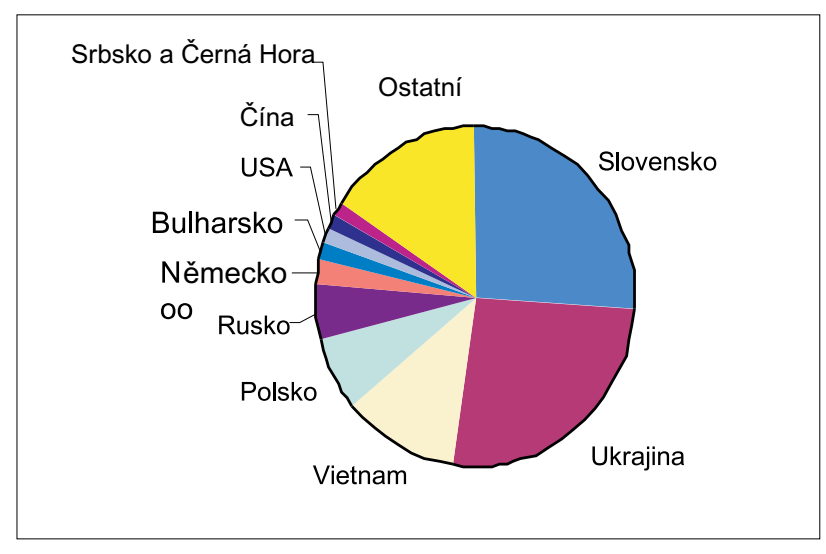

Průměrný věk cizinců je 36,5 let, což je asi o 4 roky méně než průměrný věk domácího

obyvatelstva. O něco více než $50 \%$ imigrantů jsou muži. Podíl dětí do 14 let tvoří kolem $10 \%$ a má v průběhu vývoje od roku 1993 tendenci k poklesu. Podíl imigrantů nad 60 let je o něco nižší, kolem 9 let a podstatně se nemění. Podíl imigrantů v aktivním věku má slabou tendenci k růstu a v roce 2000 dosahoval 81,8\%.

Z celkového počtu cizinců v ČR je 79,5\% zaměstnáno, z toho $38 \%$ jsou podnikatelé. Slovenští občané nepotřebují pracovní povolení, musí se pouze zaregistrovat u pracovních úřadů. Pracují převážně jako zaměstnanci, pouze asi $10 \%$ jsou podnikatelé. Ukrajinští občané jsou zhruba z $50 \%$ podnikatelé, z $50 \%$ zaměstnanci. Vietnamští občané jsou v naprosté většině podnikatelé (obchodníci). Vzhledem k předpokládanému rušení tržnic s vietnamskými obchodníky budou tito podnikatelé zřejmě nuceni hledat jiné zaměstnání, resp. jiné území. Na druhé straně roste v ČR počet manažerů ze západních zemí, převážně ze zemí EU.

Vysoké procento zaměstnanosti legálních imigrantů v České republice je významným ukazatelem z hlediska placení sociálních příspěvků. Srovnání s Rakouskem a Německem ukazuje, že podíl pracujících imigrantů je daleko nižší, v Rakousku cca $44 \%$, v Německu cca $30 \%$. Tyto rozdíly jsou pravděpodobně dány tím, že imigrace v uvedených dvou zemích je dlouhodobou záležitostí, kdy emigranti již vytvořili vícečetné rodiny, žijí tam již i důchodci- imigranti (pokud ještě tyto emigrantské rodiny nezískaly občanství). V ČR je také jiná skladba imigrace. Velké procento slovenských a ukrajinských pracovníků, kteří tvoří v ČR přes $50 \%$ imigrantů, přichází bez rodin a vrací se domů. Tato fakta však mají velký dopad na roli imigrace v budoucím vývoji společnosti, především v omlazování stárnoucí společnosti, a o roli imigrace je nutno dělat velmi opatrné soudy na základě hlubokých rozborů, včetně mezinárodního srovnání.

\subsection{Ekonomické aktivity imigrantů v Čechách}

Cizinci pracují téměř ve všech odvětvích národního hospodářství, ale převážně jsou soustředěni ve zpracovatelském průmyslu, ve stavebnictví, v zemědělství a v obchodních službách. 
Cizinci v hlavním zaměstnání podle OKEČ, roční průměry

tis. osob

\begin{tabular}{|l|c|c|c|c|c|c|}
\hline \multirow{2}{*}{ Odvětví } & \multicolumn{2}{|c|}{1999} & \multicolumn{2}{c|}{2000} & \multicolumn{2}{c|}{2001} \\
\cline { 2 - 8 } & tisíc & $\%$ & tisíc & $\%$ & tisíc & $\%$ \\
\hline Celkem & 209,0 & 100 & 194,4 & 100 & 202,3 & 100 \\
\hline
\end{tabular}

\begin{tabular}{|l|r|r|r|r|r|r|}
\hline Zemědělství, myslivost, lesnictví, rybolov & 27,1 & 13,0 & 26,0 & 13,4 & 27,2 & 13,4 \\
\hline Dobývání nerostných surovin & 7,5 & 3,6 & 7,8 & 4,0 & 8,1 & 4,0 \\
\hline Zpracovatelský průmysl & 72,2 & 34,6 & 67,0 & 34,5 & 70,0 & 34,6 \\
\hline Elektřina, plyn, voda & 7,5 & 1,9 & 3,6 & 4,0 & 8,1 & 4,0 \\
\hline Stavebnictví & 56,0 & 26,8 & 49,2 & 25,3 & 51,2 & 25,3 \\
\hline Obchod, opravy & 19,5 & 9,3 & 17,6 & 9,1 & 17,8 & 8,8 \\
\hline Pohostinství, ubytování & 4,7 & 2,3 & 4,0 & 2,1 & 4,1 & 2,0 \\
\hline Doprava, skladování, pošty a telekomunikace & 2,5 & 1,2 & 3,0 & 1,5 & 3,0 & 1,5 \\
\hline Školství & 3,4 & 1,6 & 3,5 & 1,8 & 3,7 & 1,8 \\
\hline Zdravotnictví, veterinář., sociální činnosti & 0,6 & 0,3 & 0,7 & 0,3 & 0,7 & 0,3 \\
\hline Ostatní & 7,7 & 3,6 & 8,1 & 4,1 & 8,2 & 4,1 \\
\hline
\end{tabular}

Zdroj: Cizinci v České republice, 2002, ČSÚ, str. 112. Podrobnější údaje viz dále str. 113-118.

Demografický vývoj a jeho projekce signalizující stárnutí společnosti vedly k úvahám o aktivním řízení imigrace ve většině evropských zemí, s cílem využít přednosti pozitivních rysů imigrace. Dopady stárnutí mohou být ovšem pomocí imigrace, jak bylo řečeno výše, řešeny pouze částečně, jestli vůbec. Ale řízená migrace může pokrýt poptávku po kvalifikované práci. Proto na základě vládního nařízení byl vypracován, podobně jako např. ve Švédsku a Švýcarsku, Pilotní projekt 2000 o tom, jak vyhledat kvalifikované pracovní síly s předchozí praxí, které by měly zájem o práci v ČR a současně byly přínosem pro konkrétní odvětví ČR. Pracovní místa nemají ovšem být obsazena cizími pracovníky, pokud jsou $\mathrm{k}$ dispozici na tato místa čeští pracovníci. Významnou roli hrají, jak bylo řečeno, rozdílné pracovní náklady. Pilotní projekt stanoví kriteria výběru, kvót, administrativní procedury a finanční náklady vyhledávání kvalifikovaných pracovních sil ze zahraničí. V první etapě bude projekt testován na limitovaném rozsahu vydaných pracovních povolení, asi 600 v prvním roce, $v$ druhém maximálně 1400 , pro emigranty ze tří zemí: Bulharska, Chorvatska, Kazachstánu (proč právě tyto tři země byly vybrány, není v projektu zdůvodněno). Na základě zkušeností z první etapy by měl být projekt rozšířen na více zemí a imigrantů. Každé dva měsíce bude realizace projektu hodnocena. Aktivní řízení imigrace bude realizováno postupně, jako dlouhodobý úkol. Jeho dopady budou jak do sféry pracovního trhu, tak do sociální sféry. Dnešní imigranti, pokud v ČR zůstanou, budou zítřejší důchodci a jejich děti budou pracovní silou. Proto je nutné počítat nejen s dnešními přínosy a náklady imigrace, ale i s budoucími. To však je obtížný úkol, pro jehož řešení není dostatek empirických zkušeností ani modelových řešení.

Takto koncipované vyhledávání „lidského kapitálu“ znamená, že jde o přesun kvalifikované pracovní síly z východu na západ. Současně také nelze nijak zabránit českým kvalifikovaným pracovníkům, aby nereagovali na lukrativní nabídky z bohatších zemí. Jde tedy o dilema, zda dát přednost podpoře domácí kvalifikované pracovní síly, nebo zahraniční. Teoretická úvaha nás povede $\mathrm{k}$ tomu, že rozdíly ve mzdách a životních nákladech v současné době jsou jak na východ, tak na západ od nás tak velké, že je jen nepatrná spojitost mezi těmito dvěma alternativami a zřejmě bude výhodnější pro současnou dobu nákup kvalifi- 
kované pracovní síly pro ČR z východu. (Absolutní výhody v tomto směru mají USA, které skupují kvalifikované síly v celém světě, včetně západní Evropy, ale většina jich - zjednodušeně řečeno - vzhledem $\mathrm{k}$ vyspělosti země nikam neemigruje). Pokud jde o špičkové odborníky, pak je nutno je v kterékoliv zemi přeplatit.

\subsection{Očekávaná migrace pracovní síly po vstupu do EU}

Obavy starých členských zemí EU z velkého př́livu pracovníků z nových členských zemí vedly $\mathrm{k}$ ustanovení přechodného období pro jednu ze základních svobod EU - pro oblast volného pohybu pracovní síly. To znamená, že bude po určitou dobu platit systém, kdy si žadatelé o pracovní pobyt ve většině starých zemí EU musí obstarat pracovní povolení. Tyto obavy jsou motivovány jednak již zmíněným předchozím značným nárůstem imigrantů, jednak ekonomickou situací starých zemí EU, kde jsou v posledních letech minimální př́růstky HDP a značná nezaměstnanost (v Německu jsou tyto problémy umocněny pomocí, kterou poskytuje a bude ještě 15 let poskytovat svým východním územím) i vývojem na trhu práce v nových členských zemích.

Uvolnění pracovního trhu bylo v EU zaváděno postupně i u předchozích přistupujících zemí (v případě přistoupení Španělska a Portugalska to bylo zpočátku 7 až 10 let, toto období však bylo postupně zkracováno). $V$ současné době pro nově přistupující země bylo vyjednáno přechodné období dvouleté, s možností jeho prodloužení až na sedm let. Po dvou letech bude Evropskou komisí vypracována zpráva o situaci v oblasti migrace pracovní síly a členské země by měly oznámit, jaký systém si přejí nadále uplatňovat. Podle dosavadních zkušeností se očekává, že již po těchto dvou letech řada zemí trh práce uvolní. Po dalších třech letech budou zbývající členské země opět vyzvány, aby uvolnily trh práce. Pokud v některých zemích zůstanou omezení v tomto směru, musí být definitivně zrušena po dalších dvou letech. Předpokládá se, že dosavadní členské země budou trh práce ve vztahu k nově přistupujícím postupně uvolňovat i v souvislosti $\mathrm{s}$ očekávaným zlepšování ekonomické situace v Evropě. V současné době uvolňuje trh práce pro kandidátské země s menšími omezeními pouze Irsko a Velká Británie, největší obavy z imigrace pracovní síly vyjadřuje Německo a Rakousko, jako země s největším procentem zahraničních pracovníků.

Z výzkumných pracî a zejména terénního výzkumu vyplývá lichá obava těchto dvou zemí z masové imigrace pracovníků z ČR.

Situaci v ČR však nelze ztotožňovat se situací v jiných zemích, jejichž občané pracují nebo hodlají pracovat v Německu a Rakousku. Největší podíl cizích pracovníků v těchto dvou zemích, jak bylo ukázáno výše, tvoří občané bývalé Jugoslávie a Turecka, pro které jsou tyto dvě země (kromě Švédska a Švýcarska) atraktivním cílovým regionem a kteří zřejmě i nadále budou v nich hledat zaměstnání. Ale ve větší míře také občané Polska, s ohledem na jejich emigrační zkušenosti a vysokou míru nezaměstnanosti, která v roce 2001 dosahovala v průměru $18,1 \%$. Proto jsou pochopitelné obavy v Německu a Rakousku o pracovní místa vlastních pracovníků a proto tlak na přechodné období, které je vlastně v prvních dvou letech zkušebním obdobím ověřujícím tlak na trh práce. Tyto obavy se přenášejí i na vztahy k ČR a dalším novým členským zemím. Ostatně, určité obavy mohou vzniknout i v ČR z nadměrné imigrace zejména z Polska a z dalších východních zemí, zejména Ukrajiny.

Od roku 2006 se podle nových směrnic, schválených Evropským parlamentem v březnu 2004, dále zjednodušuje získání trvalého pobytu v kterékoliv členské zemi pro občany EU, kdy bude možná pouze registrace po pětiletém legálním pobytu. Toto ustanovení

4 Práce VÚPSV, 2002. 
bude platit i zpětně (pro občany nových členských zemí ovšem až od května 2004). Zůstává však povinnost prokázat dostatečné př́ijmy na živobytí. Doplňme, že členské země EU mají přednost na trhu práce před cizinci z nečlenských zemí. Předpokládá se, že záměry jednotlivých členských zemí liberalizovat př́istup na trh práce budou i předmětem bilaterálních konzultací mezi ČR a starými členskými zeměmi EU.

Lze tedy očekávat změny v dosavadních trendech emigrace pracovní síly z ČR?

Odhady trendů migrace mohou být jen velmi nejisté. Na jedné straně trvající poměrně vysoká nezaměstnanost $\mathrm{v}$ ČR může podporovat rozhodování $\mathrm{k}$ hledání práce v zahraničí a zvyšovat poptávku po ní. Dá se očekávat, že tato poptávka bude směrována u střední a starší generace do sousedních a bližších zemí, u mladší generace do anglofonních zemí. Tento trend však bude tlumen vývojem situace na trhu práce zemí EU i vzdálenějších zemí. Již dnes mají různé země své limity pro přijímání pracovní síly pro různá zaměstnání a tyto limity se mění v souvislosti se situací na trhu práce. Specifická situace bude zřejmě nadále u sezónních prací, tedy prací na tříměsiční pobyt a u pracovníků žádoucích kvalifikací. Zatímco u pracovníků sezónních bude rozhodovat o jejich rozsahu situace na trhu práce a objem prací, př́ípadně úrody, včetně konkurence pracovníků z různých zemí, trh práce kvalifikovaných pracovníkủ bude ve větší míre předmětem předpisů ochraňujících na jedné straně zemi původu před únikem kvalifikované pracovní síly, na druhé straně v zemi určení předmětem stimulů na pomoc jejího získávání. Kromě vnitřních opatření v každé zemi tyto problémy by zřejmě měly být řešeny bilaterálními dohodami. Tak jak se bude zvyšovat v dlouhodobější perspektivě ekonomická a životní úroveň v ČR a přibližovat se úrovni vyspělých zemí, budou se normalizovat i vztahy na trhu práce, které jsou konec konců určující pro rozsah a strukturu migračních proudů.

Poznámka na závěr: Je nutno rozeznávat volný pohyb pracovních sil a svobodu pohybu občanů Evropské unie. Občané z nových členských zemí budou moci volně cestovat a odejít žít do starých členských států EU, pokud budou mít prostředky k životu - rodinní př́slušníci pracovníků, důchodci, studenti. Již dnes tam mohou působit jako samostatně výdělečně činné osoby, mohou zakládat podnikatelské subjekty (s určitými omezeními v Německu a Rakousku, kde není zatím umožněno brát s sebou zaměstnance). Po vstupu do EU je občanům uznávána profesní kvalifikace, takže zakládání podnikatelských subjektů a zaměstnávání by mělo být zjednodušeno.

\section{Vnitřní migrace obyvatelstva ČR}

Obraz o migračních proudech v ČR by nebyl úplný, kdyby nepostihoval vnitřní pohyby obyvatelstva, které mají některé společné rysy se zahraniční migrací a částečně ji i vysvětlují.

Česká republika patří k zemím s nízkou mobilitou obyvatelstva. Platí to jak o zahraniční mobilitě, tak vnitřní. Pojednání o vnitřní mobilitě pouze doplňuje předchozí studii a mělo by být samostatným předmětem zájmu ekonomů a sociologů.

\subsection{Důvody nízké vnitřní mobility obyvatelstva}

Důvody spočívajív tradiční neochotě, hlavně starších generací, ke stěhování i v tradičním dědění bytů. Stárnutí obyvatelstva sotva bude přispívat ke změně těchto tradic. Svưj podíl na této situaci má po dlouhá léta minulého režimu nepružný trh práce a existující přezaměstnanost, s jejímiž důsledky se potýká těžce společnost dodnes. Avšak hlavním faktorem, který v současné době podporuje zhoršování mobility pracovní síly, je špatně 
fungující trh s byty. Vývoj v dlouhodobé řadě ukazuje dokonce klesající procento vnitřní mobility obyvatelstva $\mathrm{v}$ průběhu devadesátých let (viz Tabulka $16 \mathrm{v}$ př́lloze) v porovnání i s předchozími desetiletími, kdy byla mobilita obyvatelstva vyšší vzhledem k možnosti měnit dekrety na byty. Teprve v letech 2001 a 2002 dochází k určitému vzestupu.

Paradoxně k poklesu mobility obyvatelstva přispívala a přispívá privatizace bytů, zejména prodeje komunálních bytů za nízké ceny v oblastech, kde je dnes vysoká nezaměstnanost. Tím vlastně obce vázaly pracovní sílu na bydliště a kromě toho podporovaly bohatší složky obyvatelstva, které si byty mohly koupit. Snižoval se tím také počet potenciálních sociálních bytů pro potřebné obyvatelstvo. Získané prostředky za prodeje bytů přitom obce mohou ztratit na sociálních dávkách pro bydlení a na nájemném, o které přišly prodejem bytů. Také dosud regulované nájemné znemožňuje výměny bytů, protože nové nájemní smlouvy pronajímají byty za vyšší ceny. Tato fakta negativně ovlivňují potřebnou mobilitu pracovní síly, zvláště v souvislosti s rostoucími problémy nezaměstnanosti a zejména s velkými regionálními rozdíly v míře nezaměstnanosti. Neuspořádaný trh s byty zvyšuje tudíž míru nezaměstnanosti. Levné hypotéky a podpora stavebního spoření určené pro movitější vrstvy obyvatel svým způsobem prohlubují majetkovou diferenciaci obyvatelstva v oblasti bydlení a neřeší problém mobility obyvatelstva.

V současné době je bydlení rozděleno mezi vlastníky následovně: podíl soukromého bydlení činí $46 \%$, nájemních bytů $31 \%$, družstevních bytů $19 \%$, ostatních $4 \%$.

Statistická data udávala v roce 2002 21,9 případů vnitřního stěhování na 1000 obyvatel. Např. sousední Rakousko má dvojnásobnou vnitřní mobilitu obyvatelstva. Poměrně nejvyšší pohyb zaznamenáváme v ČR mezi obcemi téhož okresu - okolo $50 \%$, mezi okresy téhož kraje $16 \%$, mezi kraji $30 \%$ a uvnitř Prahy mezi jejími obvody okolo $12 \%$.

\subsection{Struktura vnitřní mobility obyvatelstva $\mathrm{z}$ hlediska velikosti obcí}

Specifickým rysem pohybu obyvatelstva ČR v posledních letech je pozitivní migrační bilance malých obcí a dále obcí do deseti tisíc obyvatel - převažující počet přistěhovalých nad počtem vystěhovalých. Obce nad deset tisíc obyvatel mají negativní migrační bilanci.

Obce do 2000 obyvatel jsou definovány v tradiční statistice Č ${ }^{5}$ jako venkovské oblasti, avšak vzhledem $\mathrm{k}$ hustotě obyvatelstva $\mathrm{v}$ českých zemích se $\mathrm{v}$ mnoha př́padech $\mathrm{z}$ tohoto hlediska jako o venkově nedá mluvit. Také je to v rozporu s velkým úbytkem zemědělských pracovníků v průběhu transformace ekonomiky.

Hlavním důvodem tohoto trendu v pohybu obyvatelstva $\mathrm{z}$ větších obcí do menších jsou zejména omezené možnosti a vysoké ceny bydlení a pozemků pro novou bytovou výstavbu ve velkých městech. Proto obyvatelé (vedle dalších důvodů, jako je např. čistší vzduch pro děti) preferují přesídlení do příměstských obcí a dojíždění do práce do blízkých velkých měst, což umožňuje relativně vyspělá infrastruktura a vlastnictví osobních automobilů. Důkazem tohoto trendu je následující tabulka, znázorňující pozitivní migrační bilanci v malých obcích $\mathrm{v}$ průběhu devadesátých let a rostoucí záporné migrační saldo ve velkých obcích.

5 Statistika OECD, potažmo EUROSTATU, použivá jiná hlediska pro určení venkovského obyvatelstva, podrobněji viz „Zelená zpráva 2002“, Ministerstvo zemědělství ČR. 
Migrační bilance podle velikosti obcí

\begin{tabular}{|c|c|c|c|c|c|c|c|c|}
\hline Počet obyvatel v obci & 1992 & 1996 & 1997 & 1998 & 1999 & 2000 & 2001 & 2002 \\
\hline - 400 & $-5,2$ & 1,3 & 2,6 & 4,9 & 5,9 & 5,7 & 3,9 & 5,8 \\
\hline $500-999$ & 0,1 & 4,6 & 6,0 & 5,9 & 6,3 & 6,3 & 5,6 & 6,9 \\
\hline $1000-1999$ & 2,8 & 3,7 & 5,1 & 6,0 & 5,8 & 6,2 & 6,2 & 6,9 \\
\hline $2000-4999$ & 2,5 & 3,5 & 4,3 & 5,3 & 4,3 & 4,5 & 3,7 & 4,3 \\
\hline $5000-9999$ & 1,9 & 1,4 & 1,5 & 0,3 & 0,4 & $-0,7$ & $-0,2$ & 1,2 \\
\hline $10000-19999$ & 1,4 & 0,3 & $-0,3$ & $-0,6$ & $-1,1$ & $-1,2$ & $-3,1$ & $-2,2$ \\
\hline $20000-49999$ & 1,3 & $-0,9$ & $-1,8$ & $-2,5$ & $-2,9$ & $-2,7$ & $-4,0$ & $-4,1$ \\
\hline $50000-99999$ & $-0,1$ & $-1,7$ & $-1,9$ & $-2,8$ & $-3,4$ & $-4,6$ & $-5,8$ & $-4,8$ \\
\hline $100000+$ & 2,7 & $-0,2$ & $-0,4$ & $-1,8$ & $-1,4$ & $-1,7$ & $-5,4$ & 0,8 \\
\hline
\end{tabular}

Bude nezbytné tento mimořádný vývoj a jeho případné změny dále sledovat, zejména s růstem míry nezaměstnanosti v poslední době a jejími regionálními odlišnostmi.

Mezi statisticky sledovanými důvody vnitřní migrace, kterými jsou změna pracovního místa, stěhování blíže k pracovnímu místu, následování člena rodiny, sňatky, rozvody, bydlení a zdraví, mají první dva faktory - změna pracovního místa a stěhování blíže k pracovnímu místu - malou váhu. V roce 1999, kdy nezaměstnanost dosahovala 8,5 \%, tyto dva důvody představovaly pouze $6 \% \mathrm{z}$ celkového množství vnitřní migrace, a toto procento zůstalo stejné v roce 2002, kdy vzrostla míra nezaměstnanosti na $10 \%$. Hlavní váhu v důvodech vnitřní migrace mají rodinné důvody. Zdálo by se tedy, že interní stěhování není citlivé na míru nezaměstnanosti.

Můžeme však obecně předpokládat určité časové zpoždění mezi růstem míry nezaměstnanosti a stěhováním pracovní síly za prací. Nacházíme také určité rozdíly v pohybu obyvatelstva mezi regiony s vysokou a nízkou mírou nezaměstnanosti: Praha a střední Čechy, kde je míra nezaměstnanosti nejnižší, mají pozitivní čistou migraci, na druhé straně regiony severních Čech a severní Moravy mají negativní čistou migraci. (Podrobnější informaci obsahují tabulky H 02.01 a H 03 na adrese www.czso.cz.)

\subsection{Mobilita cizinců uvnitř ČR}

Specifické trendy ve vnitřní migraci vykazuje stěhování cizinců: $50 \%$ z ní jsou Ukrajinci, kteří vykonávají sezónní práce, hlavně zemědělské a stavební, a stěhují se za nimi. Podobné motivace mají i slovenští pracovníci. Jiný trend vykazuje mobilita vietnamských imigrantů, převážně obchodníků, kteří se postupně stěhují do menších měst. Tento trend lze vysvětlit tím, že poptávka po jejich zboží je ve větších městech již nasycena a současně jejich počet dosud roste, takže musí hledat nová odbytiště. O jejich případných změnách zaměstnání a povolání byla již zmínka výše.

Toto stručné pojednání o vnitřní migraci v ČR je pouze úvodem do závažné problematiky vnitrozemské mobility pracovní síly. Obecně se dá předpokládat, že konzervativní postoje obyvatelstva k vnitřnímu přesídlování se budou měnit s rozvojem ekonomiky a novými nabídkami trhu práce zejména pro mladé lidi. Nezbytným předpokladem pro změnu postojů ke stěhování bude i odpovídající bytová politika. 


\section{Závěry}

Pojem migrace obyvatelstva nabyl pro Českou republiku v průběhu devadesátých a dalších let nový obsah. Stala se ze země převážně emigrantské, kterou byla v minulém režimu, zemí emigrantsko-imigrantskou, s postupnou převahou imigrantů, tedy zemí s aktivní migrační bilancí a postupně i z tranzitní země zemí rezidentní.

Tímto vývojem se přiblí̌zila k rozvinutým evropským zemím, avšak ve srovnání s nimi má dosud nízkou míru imigrace. Dá se předpokládat, že tato míra poroste vlivem přílivu pracovníků, v nejbližší době zejména z východních zemí. Půjde však o to, aby tato imigrace byla legální a potřebná. To bude klást velké nároky na legislativu, na imigrační politiku i na konkrétní opatření včetně ochrany hranic. Legální a řízená imigrace bude i v budoucnu potřebná jednak pro doplnění pracovníků v sezónních pracích, zejména ve stavebnictví, jednak pro doplnění kvalifikované pracovní síly zejména mladými lidmi. Skloubit migrační trendy s využitím domácích pracovníků je však velmi náročné a nelze se omezit pouze na ekonomickou stránku věci. V mnoha případech by bylo jednodušší využívat pouze nabízející se levnou pracovní sílu ze zahraničí a nezatěžovat se obtîžným řešením problémů zaměstnávání domácí nekvalifikované pracovní síly. Následky v podobě rostoucí nezaměstnanosti a rostoucích sociálních podpor by se opět projevily jako ekonomické ztráty.

Role imigrace v zastavení stárnutí a v případném omlazování české společnosti je pouhou hypotézou a není dosud dostatečně prozkoumána. Bylo by třeba uvažovat nejen současné výhody a rizika, ale i budoucí náklady a zisky imigrace. To je však velmi obtížné a proto o roli imigrace je nutno dělat velmi opatrné soudy a na základě hlubokých rozborů, včetně mezinárodního srovnání.

Uvolnění trhu práce po vstupu ČR do EU nebude mít za následek masové odchody českých občanů do bohatších členských zemí z několika důvodů. Jednak dosud nepřekonaná neochota ke stěhování, a to i uvnitř státu, jednak značně vysoké vedlejší náklady emigrace. Určitým ukazatelem očekávaných odchodů pracovníků do zahraničí může být i snižující se trend všech forem emigrace z ČR v posledních letech. Dočasné studijní a výměnné pobyty mladé populace jsou však žádoucí a bylo by vhodné je podporovat.

Vývoj migrace obyvatelstva je úzce spojen s vývojem ekonomiky a trhu práce a jejich vzájemným působením. To budou konec konců faktory, které budou určovat migrační proudy pracovní síly v budoucnosti. 


\section{Literatura}

1. BURCIN, B. - KUČERA, T.: Perspektivy populačního vývoje České republiky na období 2003-2065. 2003.

2. Cizinci v České Republice. Český statistický úřad, 2002.

3. CZECH REPUBLIC 2003/4, CERGE - EI, 2004, část VII.

4. FIDRMUC, J.: Migration and regional adjustment to asymmetric shocks in transition economies. CPB Discussion Paper 007, 2002.

5. HÁRS, A. (2002): Hungarian emigration and immigration perspektives - some economic considerations. South-East Europe Review, s. 111-130.

6. Mezinárodní politika 10/2003, ročník XXVII, Pohyb obyvatelstva a stěhování národů, Praha, Ústav Mezinárodních vztahů.

7. NAHUIS, R., PARIKH, A.: Factor Mobility and Regional Disparities: East, West, Home's Best?" CPB Discussion Paper No 004, The Haag, 2002.

8. PAVLÍK, Z. a kolektiv: Vývoj obyvatelstva České republiky 1990-2002. 2002.

9. ROODENBURG, H. - EUWALS, R. - RELETER, H.: Immigration and the Dutch Ekonomy, CPB, The Haag, 2003.

10. Statistická ročenka České republiky 2003.

11. VAVREČKOVÁ, J., FISCHLOVÁ, D., JANATA, Z.: Migrační potenciál př́hraničí České republiky s Německem. Výsledky empirického šetření, VÚPSV, 2001.

12. World Population Trends. OSN, Monitoring Report, 1985, Volume 1.

13. Zelená zpráva 2002. Praha, Ministerstvo zemědělství.

14. http//www.mvcr.cz/dokumenty/migrace/2002/zprava.02.doc. 


\section{Tabulková příloha}

Pramen údajů pro tabulky 1 a 2: Statistická ročenka ČR 2003, str. 660 a 663 pro tabulky 2-10: http//www.mvcr.cz/dokumenty/migrace/2002/zprava.02.doc

Tabulka 1

Migrace a obyvatelé s cizí státní př́slušností v zemích EU a zemích

\begin{tabular}{|c|c|c|c|c|c|c|}
\hline \multirow[t]{2}{*}{ Země } & \multicolumn{3}{|c|}{$\begin{array}{c}\text { Míra čisté migrace } \\
(\%)\end{array}$} & \multicolumn{3}{|c|}{$\begin{array}{c}\text { Obyvatelstvo s cizí státní príslušností } \\
\text { (podíl z celkového oby- } \\
\text { vatelstva } \vee \%)\end{array}$} \\
\hline & 1995 & 2000 & 2001 & 1996 & 2000 & 2001 \\
\hline Belgie & 0,01 & 0,13 & . & 9,0 & 8,8 & 8,4 \\
\hline Dánsko & 0,55 & 0,19 & 0,22 & 4.2 & 4,9 & 4,8 \\
\hline Finsko & 0,08 & 0,05 & 0,12 & 1,3 & 1,7 & 1,8 \\
\hline Francie & 0,07 & 0,08 & 0,10 & . & . & . \\
\hline Irsko & 0,16 & 0,70 & 0,68 & 3,3 & 3,3 & 4,0 \\
\hline Itálie & 0,17 & 0,31 & . & 1,3 & 2,2 & . \\
\hline Lucembursko & 1,12 & 0,43 & 0,63 & 33,4 & 36,6 & 36,9 \\
\hline Německo & 0,49 & 0,20 & 0,32 & 8,8 & 8,9 & 8,9 \\
\hline Nizozemí & 0,10 & 0,36 & 0,34 & 4,7 & 4,1 & 4,2 \\
\hline Portugalsko & 0,25 & 0,49 & 0,63 & 1,7 & 1,9 & . \\
\hline Rakousko & 0,09 & 0,21 & 0,21 & 9,0 & 9,3 & 9,4 \\
\hline Řecko & 0,20 & 0,12 & . & 1.5 & . & . \\
\hline Spojené království & 0,18 & 0,28 & 0,31 & 3,4 & 4,2 & . \\
\hline Španelsko & 0,09 & 0,88 & 0,60 & 1,3 & 2,3 & 2,2 \\
\hline Švédsko & 0,13 & 0,27 & 0,32 & 6,0 & 5,5 & 5,4 \\
\hline Bulharsko & 0,00 & 0,00 & 0,00 & . & . & 0,3 \\
\hline Česká republika & 0,10 & 0,06 & 0,20 & . & 2,2 & 2,0 \\
\hline Estonsko & $-1,08$ & 0,02 & 0,01 & . & 20,0 & . \\
\hline Kypr & 0,06 & 0,11 & 0,41 & 3,0 & 3,2 & 3,2 \\
\hline Litva & $-0,65$ & $-0,58$ & $-0,07$ & . & . & 0,9 \\
\hline Lotyšsko & $-0,55$ & $-0,23$ & $-0,22$ & 0,5 & 1,2 & 1,3 \\
\hline Mad'arsko & 0,17 & 0,16 & 0,10 & 1,4 & 1,5 & 1,1 \\
\hline Malta & $-0,05$ & 0,27 & 0,59 & 1,9 & 2,3 & 2,3 \\
\hline Polsko & $-0,05$ & $-0,05$ & $-0,04$ & . & . & . \\
\hline Rumunsko & $-0,09$ & $-0,02$ & . & 0,0 & 0,0 & 0,0 \\
\hline Slovensko & 0,05 & 0,03 & 0,02 & . & & . \\
\hline Slovinsko & 0,04 & 0,14 & 0,25 & 2,4 & 2,1 & 2,1 \\
\hline Turecko & 0,17 & 0,27 & 0,31 & . & . & . \\
\hline
\end{tabular}


Tabulka 2

Míra nezaměstnanosti

\begin{tabular}{|c|c|c|c|c|c|c|c|}
\hline Země & 1995 & 1996 & 1997 & 1998 & 1999 & 2000 & 2001 \\
\hline Česká republika & 4,0 & 3,9 & 4,8 & 6,5 & 8,7 & 8,8 & 8,1 \\
\hline Belgie & 9,3 & 9,6 & 8,9 & 9,1 & 8,6 & 7,0 & 6,2 \\
\hline Bulharsko & 15,7 & 13,5 & 13,7 & 12,2 & 14,1 & 16,3 & 19,4 \\
\hline Dánsko & 7,0 & 6,9 & 6,1 & 5,5 & 5,6 & 4,6 & 4,8 \\
\hline Finsko & 15,2 & 14,4 & 12,5 & 11,3 & 10,1 & 9,7 & 9,1 \\
\hline Francie & 11,6 & 12,1 & 12,3 & 11,8 & 10,9 & 9,5 & 8,7 \\
\hline Irsko & 12,2 & 11,9 & 10,3 & 7,8 & 5,7 & 4,3 & 3,7 \\
\hline Itálie & 11,3 & 11,4 & 11,5 & 11,7 & 11,3 & 10,5 & 9,5 \\
\hline Lucembursko & 3,0 & 3,3 & 3,3 & 3,1 & 2,9 & 2,7 & 2,7 \\
\hline Mad'arsko & 10,2 & 9,9 & 8,7 & 7,8 & 7,1 & 6,5 & 5,8 \\
\hline Německo & 10,1 & 8,8 & 9,8 & 9,7 & 8,6 & 8,1 & 8,2 \\
\hline Nizozemsko & 7,1 & 6,6 & 5,5 & 4,4 & 3,5 & 3,3 & 2,7 \\
\hline Norsko & 4,9 & 4,8 & 4,0 & 3,2 & 3,2 & 3,4 & 3,6 \\
\hline Polsko & 13,3 & 12,3 & 11,2 & 10,5 & 13,9 & 16,1 & 18,2 \\
\hline Portugalsko & 7,1 & 7,2 & 6,7 & 5,0 & 4,4 & 4,0 & 4,1 \\
\hline Rakousko & 3,7 & 4,1 & 4,2 & 4,2 & 3,8 & 3,6 & 3,6 \\
\hline Rumunsko & 8,0 & 6,7 & 6,0 & 6,3 & 6,8 & 7,1 & 6,6 \\
\hline Rusko & 9,5 & 9,7 & 11,8 & 13,3 & 13,4 & . & 8,7 \\
\hline Řecko & 10,0 & 10,3 & 10,3 & 10,8 & 11,7 & 11,1 & 10,2 \\
\hline Slovensko ${ }^{2)}$ & 13,1 & 11,3 & 11,8 & 12,5 & 16,4 & 18,8 & 19,3 \\
\hline Slovinsko & 7,4 & 7,3 & 7,1 & 7,7 & 7,4 & 7,2 & 5,9 \\
\hline Spojené království & 8,6 & 8,2 & 7,1 & 6,1 & 5,9 & 5,4 & 5,1 \\
\hline Španelsko & 22,9 & 22,2 & 20,8 & 18,8 & 15,6 & 13,9 & 12,8 \\
\hline Švédsko & 7,7 & 8,0 & 8,0 & 6,5 & 5,6 & 4,7 & 4,0 \\
\hline Švýcarsko & 3,3 & 3,7 & 4,1 & 3,6 & 3,1 & 2,7 & 2,5 \\
\hline Čína ${ }^{3)}$ & 2,9 & 3,0 & 3,0 & 3,1 & 3,1 & 3,1 & 3,6 \\
\hline Japonsko & 3,2 & 3,4 & 3,4 & 4,1 & 4,7 & 4,7 & 5,0 \\
\hline Korea & 2,0 & 2,0 & 2,6 & 6,8 & 6,3 & 4,1 & 3,7 \\
\hline Kanada ${ }^{4)}$ & 9,5 & 9,7 & 9,2 & 8,3 & 7,5 & 6,8 & 7,2 \\
\hline Spojené státy & 5,6 & 5,4 & 4,9 & 4,5 & 4,2 & 4,0 & 4,8 \\
\hline Austrálie & 8,4 & 8,3 & 8,4 & 7,9 & 7,0 & 6,4 & 6,8 \\
\hline Nový Zéland & 6,3 & 6,1 & 6,6 & 7,6 & 6,8 & 6,0 & 5,3 \\
\hline EU 15 & 107 & 10,8 & 10,6 & 9,9 & 9,1 & 8,2 & 7,3 \\
\hline \multicolumn{8}{|c|}{$\begin{array}{l}{ }^{1)} \text { bez osob na rodičovské dovolené aktivně } \\
\text { si hledajících zaměstnání } \\
{ }^{2)} \text { bez osob na rodičovské dovolené } \\
{ }^{3)} \text { nezaměstnaní v městských oblastech } \\
{ }^{4)} \text { bez obyvatel Teritorií a původního obyvatelstva } \\
\text { žijícího v rezervacích }\end{array}$} \\
\hline
\end{tabular}

Tabulka 3 
Legální migrace - cizinci s povoleným pobytem na území ČR

\begin{tabular}{|c|c|c|c|c|c|c|c|c|c|c|c|}
\hline $\begin{array}{c}\text { Stav } \\
\mathrm{K} \text { 31.12. roku }\end{array}$ & 1992 & 1993 & 1994 & 1995 & 1996 & 1997 & 1998 & 1999 & 2000 & 2001 & 2002 \\
\hline Účinnost zákona & \multicolumn{8}{|c|}{ č.123/1992 Sb. } & \multicolumn{3}{|c|}{ č.326/1999 Sb. } \\
\hline $\begin{array}{c}\text { Celkem cizinců s povoleným } \\
\text { pobytem v ČR * }\end{array}$ & 49957 & 77668 & 104343 & 159207 & 199152 & 210311 & 220187 & 228862 & 200951 & 210794 & 231608 \\
\hline tj.\% & 100,0 & 100,0 & 100,0 & 100,0 & 100,0 & 100,0 & 100,0 & 100,0 & 100,0 & 100,0 & 100,0 \\
\hline Meziroční změna & & +27711 & +26675 & +54864 & +39945 & +11 159 & +9876 & +8675 & -27911 & +9843 & +20814 \\
\hline \multicolumn{12}{|l|}{$z$ toho } \\
\hline Trvalý pobyt & 29145 & 31072 & 32468 & 38557 & 45837 & 56281 & 63919 & 66754 & 66891 & 69816 & 75249 \\
\hline tj. $\%$ & 58,3 & 40,0 & 31,1 & 24,2 & 23,0 & 26,8 & 29,0 & 29,2 & 33,3 & 33,1 & 32,5 \\
\hline Meziroční změna & & +1927 & +1396 & +6089 & +7280 & +10444 & +7638 & +2835 & +137 & +2925 & +5433 \\
\hline Pobyt na vízum nad 90 dní ** & 20428 & 46070 & 71230 & 120060 & 152767 & 153516 & 155836 & 162108 & 134060 & 140978 & 156359 \\
\hline tj.\% & 40,9 & 59,3 & 68,3 & 75,4 & 76,7 & 73,0 & 70,8 & 70,8 & 66,7 & 66,9 & 67,5 \\
\hline Meziroční změna & & +25642 & +25160 & +48830 & +32707 & +749 & +2320 & +6272 & -28048 & +6918 & +15381 \\
\hline \multirow{2}{*}{ Bez státní př́slušnosti ${ }^{* * *}$} & 384 & 526 & 645 & 590 & 548 & 514 & 432 & 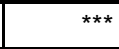 & 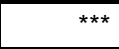 & $\star \star \star *$ & $\star \star \star$ \\
\hline & 0,8 & 0,7 & 0,6 & 0,4 & 0,3 & 0,2 & 0,2 & *** & *** & *** & 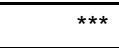 \\
\hline \multicolumn{12}{|c|}{ Cizinci s trvalým pobytem $v$ ČR $-z$ toho nejvíce občanů * } \\
\hline Polska & 11955 & 12580 & 11910 & 12071 & 12086 & 11940 & 12034 & 11598 & 11769 & 11592 & 11326 \\
\hline Slovenska & $\mathrm{N}$ & 631 & 2960 & 6540 & 9921 & 12689 & 14127 & 13018 & 11129 & 10850 & 10996 \\
\hline Ukrajiny & 528 & 1208 & 1563 & 2120 & 2769 & 4632 & 6240 & 7790 & 8774 & 9909 & 10704 \\
\hline Vietnamu & 712 & 1004 & 1083 & 1469 & 2519 & 5121 & 6785 & 7954 & 8238 & 9901 & 13372 \\
\hline Ruska & 881 & 663 & 1734 & 1670 & 1971 & 2475 & 2874 & 3486 & 3806 & 4097 & 4459 \\
\hline SRN & 835 & 966 & 1272 & 1696 & 2013 & 2261 & 2536 & 2517 & 2536 & 2535 & 2608 \\
\hline Bulharska & 2931 & 2877 & 2632 & 2686 & 2457 & 2352 & 2334 & 2331 & 2302 & 2166 & 2164 \\
\hline Rumunska & 542 & 550 & 619 & 804 & 1138 & 1384 & 1621 & 1714 & 1726 & 1737 & 1715 \\
\hline Srbska a Černé Hory & 1 & 4 & 91 & 107 & 1445 & 1620 & 1831 & 1747 & 1691 & 1658 & 1720 \\
\hline USA & 759 & 1015 & 1234 & 1427 & 1718 & 1880 & 1938 & 1826 & 1647 & 1506 & 1467 \\
\hline \multicolumn{12}{|c|}{ Pobyt na vízum nad 90 dní ** - z toho nejvíce občanů * } \\
\hline Slovenska & 2 & 1795 & 13818 & 33185 & 40334 & 39489 & 35494 & 27344 & 33136 & 42444 & 50106 \\
\hline Ukrajiny & 320 & 4809 & 12667 & 26038 & 43534 & 38770 & 46444 & 58093 & 41438 & 41916 & 48441 \\
\hline Vietnamu & 2838 & 6785 & 8550 & 12744 & 15101 & 15829 & 16090 & 16870 & 15318 & 14023 & 13771 \\
\hline Ruska & 80 & 525 & 1877 & 2717 & 4726 & 6463 & 7155 & 13420 & 9158 & 8326 & 8354 \\
\hline Polska & 4193 & 8655 & 8111 & 10982 & 12405 & 13079 & 10132 & 6680 & 5281 & 4897 & 4670 \\
\hline Číny & 1365 & 2543 & 2872 & 4186 & 4731 & 4433 & 4106 & 4211 & 3410 & 3138 & 2821 \\
\hline SRN & 934 & 1976 & 2923 & 3857 & 2862 & 3666 & 3712 & 3595 & 2432 & 2402 & 2575 \\
\hline Moldávie & 14 & 38 & 87 & 161 & 296 & 2093 & 3038 & 2757 & 1909 & 2160 & 2366 \\
\hline Bulharska & 617 & 1172 & 1140 & 1596 & 1845 & 4232 & 3625 & 2699 & 1716 & 1935 & 2019 \\
\hline Běloruska & $\mathrm{N}$ & 74 & 95 & 236 & 977 & 3094 & 3454 & 3526 & 2134 & 1949 & 2066 \\
\hline
\end{tabular}

Vysvětlivky: * cizinci s povoleným pobytem $v$ ČR - tj. s pobytem trvalým a pobytem na vízum nad 90 dnů

** pobyt na vízum nad 90 dní (do 31.12.1999 odpovídal pobytu dlouhodobému)

*** od roku 1999 osoby bez státní príslušnosti zařazeny dle druhu pobytu na území ČR

Tabulka 4 
Legální migrace - vývoj počtu platných povolení k zaměstnání vydaných cizincům v roce 2002

\begin{tabular}{|r|l|r|r|r|r|r|}
\hline Pořadí & \multicolumn{1}{|c|}{ Stát } & $\mathbf{1 2 / 2 0 0 1}$ & \multicolumn{1}{|c|}{$\mathbf{3 / 2 0 0 2}$} & $\mathbf{6 / 2 0 0 2}$ & $\mathbf{9 / 2 0 0 2}$ & $\mathbf{1 2 / 2 0 0 2}$ \\
\hline 1. & Ukrajina & 17473 & 17921 & 19675 & 19576 & 19958 \\
\hline 2. & Polsko & 6661 & 6672 & 6608 & 6974 & 7338 \\
\hline 3. & Bulharko & 1863 & 1859 & 1859 & 1888 & 1985 \\
\hline 4. & Moldavsko & 1377 & 1423 & 1555 & 1487 & 1412 \\
\hline 5. & USA & 1279 & 1384 & 1592 & 1332 & 1435 \\
\hline 6. & Německo & 1218 & 1242 & 1319 & 1217 & 1306 \\
\hline 7. & Bělorusko & 1028 & 1154 & 1182 & 1174 & 1191 \\
\hline 8. & Velká Británie & 989 & 1072 & 1192 & 985 & 1005 \\
\hline 9. & Mongolsko & 976 & 955 & 1021 & 1134 & 1185 \\
\hline 10. & Rusko & 887 & 914 & 955 & 881 & 930 \\
\hline 11. & Rumunsko & 764 & 737 & 691 & 684 & 724 \\
\hline 12. & Francie & 613 & 663 & 683 & 636 & 702 \\
\hline 13. & Makedonie & 435 & 363 & 376 & 336 & 395 \\
\hline 14. & Rakousko & 396 & 413 & 457 & 412 & 432 \\
\hline Zaregistrováno občanů Slovenska pracujících v ČR & 6353 & 65159 & 65193 & 56558 \\
\hline
\end{tabular}

\section{Tabulka 5}

\section{Legální migrace - počet podnikatelů a živností k 31. 12. 2002}

\begin{tabular}{|c|c|c|}
\hline Občanství & Podnikatelé & Živnosti \\
\hline Alžírsko & 328 & 390 \\
\hline Arménie & 333 & 499 \\
\hline Bělorusko & 383 & 516 \\
\hline Bosna a Hercegovina & 359 & 491 \\
\hline Bulharsko & 1004 & 1430 \\
\hline Čína & 232 & 269 \\
\hline Francie & 137 & 192 \\
\hline Chorvatsko & 441 & 613 \\
\hline Itálie & 307 & 469 \\
\hline Srbsko a Černá Hora & 1400 & 1868 \\
\hline Kazachstán & 318 & 420 \\
\hline Makedonie & 270 & 347 \\
\hline Moldavsko & 382 & 457 \\
\hline Mongolsko & 190 & 226 \\
\hline Německo & 949 & 1340 \\
\hline Nigérie & 156 & 189 \\
\hline Nizozemsko & 124 & 175 \\
\hline Pákistán & 123 & 140 \\
\hline Polsko & 1081 & 1491 \\
\hline Rakousko & 250 & 384 \\
\hline Rumunsko & 186 & 240 \\
\hline Rusko & 1667 & 2205 \\
\hline Řecko & 117 & 208 \\
\hline Slovensko & 7175 & 9464 \\
\hline Spojené království & 392 & 540 \\
\hline Spojené státy americké & 585 & 795 \\
\hline Sutinám & 101 & 132 \\
\hline Sýrie & 167 & 244 \\
\hline Tunisko & 106 & 133 \\
\hline Ukrajina & 19047 & 22870 \\
\hline Vietnam & 20081 & 23965 \\
\hline
\end{tabular}

Poznámka: Podnikatelé $=$ počet podnikatelů

Živnosti = počet živností vykonávaných podnikateli 
Tabulka 6

Nelegální migracep řes státní hranice České republiky od roku 1993 do roku 2002

\begin{tabular}{|c|c|c|c|c|c|c|c|c|c|c|c|}
\hline Rok & $\mathbf{k m}$ & 1993 & 1994 & 1995 & 1996 & 1997 & 1998 & 1999 & 2000 & 2001 & 2002 \\
\hline \multicolumn{12}{|l|}{ údaje vabsolutních číslech } \\
\hline \multicolumn{2}{|c|}{\begin{tabular}{|c|} 
Nelegální migrace přes státní hranice Č \\
- zjišst ěno osob
\end{tabular}} & 43302 & 20480 & 19172 & 23705 & 29339 & 44672 & 32325 & 32720 & 23834 & 14741 \\
\hline \multirow{2}{*}{\multicolumn{2}{|c|}{$\begin{array}{r}z \text { toho cizinc ů } \\
\text { ob čanů ČR }\end{array}$}} & 41765 & 18832 & 17132 & 21179 & 27325 & 42957 & 30377 & 30761 & 21090 & 12632 \\
\hline & & 1537 & 1648 & 2040 & 2526 & 2014 & 1715 & 1948 & 1959 & 2744 & 2109 \\
\hline \multirow{2}{*}{\begin{tabular}{r|}
$z$ toho ve sm ěruz ČR \\
ve sm èrudo ČR \\
\end{tabular}} & & 41327 & 17030 & 15374 & 18680 & 22011 & 37142 & 26951 & 27586 & 16978 & 9232 \\
\hline & & 1975 & 3450 & 3798 & 5025 & 7328 & 7530 & 5374 & 5134 & 6856 & 5509 \\
\hline $\begin{array}{r}\text { Z toho na hranicích ČR } \\
\text { s Polskem }\end{array}$ & 761 & 1245 & 1679 & 1978 & 3036 & 2954 & 2603 & 3142 & 4726 & 3976 & 3412 \\
\hline se SRN & 810,3 & 40133 & 16047 & 14407 & 16654 & 20860 & 32859 & 20170 & 20745 & 11510 & 4941 \\
\hline $\begin{array}{r}\text { s Rakouskem } \\
\text { Se SR }\end{array}$ & 467,3 & 1663 & 1320 & 1114 & 1762 & 2251 & 3480 & 5146 & 4126 & 4538 & 3463 \\
\hline \multirow{3}{*}{$\begin{array}{r}\text { se SR } \\
\text { letišt ě ČR } \\
\text { vnitrozemí }\end{array}$} & 251,8 & 243 & 1302 & 1189 & 1759 & 2544 & 3923 & 2737 & 1875 & 2661 & 1884 \\
\hline & & 18 & 105 & 396 & 385 & 560 & 677 & 404 & 342 & 222 & 144 \\
\hline & & & 27 & 88 & 109 & 170 & 1130 & 726 & 906 & 927 & 897 \\
\hline \multicolumn{12}{|l|}{ údaje v \% } \\
\hline \multirow{2}{*}{\multicolumn{2}{|c|}{\begin{tabular}{|c|} 
Nelegální migrace p řes státní hranice č \\
- zjišt ěno osob \\
\end{tabular}}} & & & & & & & & & & \\
\hline & & 100,0 & 100,0 & 100,0 & 100,0 & 100,0 & 100,0 & 100,0 & 100,0 & 100,0 & 100,0 \\
\hline \multirow{2}{*}{\multicolumn{2}{|c|}{$\begin{array}{r}\mathrm{z} \text { toho cizinc ů } \\
\text { ob čanů ČR }\end{array}$}} & 96,5 & 92,0 & 89,4 & 89,3 & 93,1 & 96,2 & 94,0 & 94,0 & 88,5 & 85,7 \\
\hline & & 3,5 & 8,0 & 10,6 & 10,7 & 6,9 & 3,8 & 6,0 & 6,0 & 11,5 & 14,3 \\
\hline \multirow{2}{*}{$\begin{array}{r}z \text { toho ve sm ěruz ČR } \\
\text { ve sm ěrudo ČR } \\
\end{array}$} & & 95,4 & 83,2 & 80,2 & 78,8 & 75,0 & 83,1 & 83,4 & 84,3 & 71,2 & 62,6 \\
\hline & & 4,6 & 16,8 & 19,8 & 21,2 & 25,0 & 16,9 & 16,6 & 15,7 & 28,8 & 37,4 \\
\hline $\begin{array}{r}\text { z toho na hranicích ČR } \\
\text { s Polskem }\end{array}$ & 33,2 & 2,9 & 8,2 & 10,3 & 12,8 & 10,1 & 5,8 & 9,7 & 14,4 & 16,7 & 23,1 \\
\hline se SRN & 35,4 & 92,7 & 78,4 & 75,2 & 70,3 & 71,1 & 73,6 & 62,4 & 63,4 & 48,3 & 33,5 \\
\hline s Rakouskem & 20,4 & 3,8 & 6,5 & 5,8 & 7,4 & 7,7 & 7,8 & 15,9 & 12,6 & 19,0 & 23,5 \\
\hline se SR & 11,0 & 0,6 & 6,4 & 6,2 & 7,4 & 8,7 & 8,8 & 8,5 & 5,7 & 11,2 & 12,8 \\
\hline letišt ě ČR & & & 0,5 & 2,1 & 1,6 & 1,9 & 1,5 & 1,2 & 1,0 & 0,9 & 1,0 \\
\hline vnitrozemí & & & 0,1 & 0,5 & 0,6 & 0,6 & 2,5 & 2,2 & 2,8 & 3,9 & 6,1 \\
\hline
\end{tabular}


Tabulka 7

Nelegální migrace přes státní hranice České republiky - podíl orgánů ochrany stáních hranic na odhalení nelegálních přechodů

\begin{tabular}{|c|c|c|c|c|c|c|c|c|c|c|}
\hline Rok & 1993 & 1994 & 1995 & 1996 & 1997 & 1998 & 1999 & 2000 & 2001 & 2002 \\
\hline $\begin{array}{c}\text { Nelegální migrace přes SH ČR } \\
\text { zjištěno osob }\end{array}$ & 43302 & 20480 & 19172 & 23705 & 29339 & 44672 & 32325 & 32720 & 23834 & 14741 \\
\hline Z toho zadrženo orgány ČR & 23392 & 10548 & 11051 & 14281 & 17734 & 25790 & 18867 & 19893 & 14523 & 9938 \\
\hline Zadrženo orgány jiných států & 19873 & 9841 & 7951 & 9165 & 11346 & 18690 & 13269 & 12684 & 8879 & 4425 \\
\hline$z$ toho orgány SRN & 18904 & 8855 & 6984 & 7712 & 9519 & 15684 & 8935 & 9288 & 5540 & 2547 \\
\hline Rakouska & 609 & 424 & 247 & 353 & 967 & 1902 & 2954 & 2016 & 1995 & 890 \\
\hline Polska & 352 & 545 & 684 & 1068 & 845 & 1080 & 1350 & 1342 & 1312 & 980 \\
\hline Slovenska & 7 & 16 & 35 & 15 & 11 & 21 & 25 & 22 & 13 & 4 \\
\hline ostatní & 1 & 1 & 1 & 17 & 4 & 3 & 5 & 16 & 19 & 4 \\
\hline Bez zadržení & 37 & 91 & 170 & 259 & 259 & 192 & 189 & 143 & 432 & 378 \\
\hline \multicolumn{11}{|l|}{ Údaje v \% } \\
\hline $\begin{array}{c}\text { Nelegální migrace přes SH ČR } \\
\text { zjištěno osob }\end{array}$ & 100,0 & 100,0 & 100,0 & 100,0 & 100,0 & 100,0 & 100,0 & 100,0 & 100,0 & 100,0 \\
\hline Z toho zadrženo orgány ČR & 54,0 & 51,5 & 57,6 & 60,2 & 60,4 & 57,7 & 58,4 & 60,8 & 60,9 & 67,4 \\
\hline Zadrženo orgány jiných států & 45,9 & 48,1 & 41,5 & 38,7 & 38,7 & 41,8 & 41,0 & 38,8 & 37,3 & 30,0 \\
\hline$z$ toho orgány SRN & 43,7 & 43,2 & 36,4 & 32,5 & 32,4 & 35,1 & 27,6 & 28,4 & 23,2 & 17,3 \\
\hline Rakouska & 1,4 & 2,1 & 1,3 & 1,5 & 3,3 & 4,3 & 9,1 & 6,2 & 8,4 & 6,0 \\
\hline Polska & 0,8 & 2,7 & 3,6 & 4,5 & 2,9 & 2,4 & 4,2 & 4,1 & 5,5 & 6,6 \\
\hline Slovenska & 0,0 & 0,1 & 0,2 & 0,1 & 0,0 & 0,0 & 0,1 & 0,1 & 0,1 & 0,0 \\
\hline ostatní & 0,0 & 0,0 & 0,0 & 0,1 & 0,0 & 0,0 & 0,0 & 0,0 & 0,1 & 0,0 \\
\hline Bez zadržení & 0,1 & 0,4 & 0,9 & 1,1 & 0,9 & 0,4 & 0,6 & 0,4 & 1,8 & 2,6 \\
\hline
\end{tabular}

\section{Tabulka 8}

Nelegální migrace přes státní hranice České republiky - rozdělení podle světadílů

\begin{tabular}{|c|c|c|c|c|c|c|c|c|c|c|}
\hline Rok & 1993 & 1994 & 1995 & 1996 & 1997 & 1998 & 1999 & 2000 & 2001 & 2002 \\
\hline $\begin{array}{l}\text { Nelegální migrace přes státní } \\
\text { hranice ČR- zjištěno osob }\end{array}$ & 43302 & 20480 & 19172 & 23705 & 29339 & 44672 & 32325 & 32720 & 23834 & 14741 \\
\hline z toho: Afrika & 1616 & 785 & 552 & 1122 & 1110 & 680 & 426 & 366 & 186 & 186 \\
\hline Amerika & 25 & 43 & 19 & 50 & 126 & 167 & 40 & 29 & 18 & 21 \\
\hline Asie & 4095 & 2328 & 6358 & 6211 & 8858 & 13109 & 13130 & 13157 & 9337 & 7063 \\
\hline Evropa & 37472 & 17230 & 11959 & 15866 & 18766 & 30334 & 18513 & 18867 & 14118 & 7257 \\
\hline Austrálie a Oceánie & 2 & 2 & 2 & & 1 & 1 & & 5 & 1 & \\
\hline Neurčeno & 92 & 92 & 282 & 456 & 478 & 381 & 216 & 296 & 174 & 214 \\
\hline \multicolumn{11}{|l|}{ Údaje $v \%$} \\
\hline $\begin{array}{l}\text { Nelegální migrace přes státní } \\
\text { hranice ČR- zjištěno osob }\end{array}$ & 100,0 & 100,0 & 100,0 & 100,0 & 100,0 & 100,0 & 100,0 & 100,0 & 100,0 & 100,0 \\
\hline z toho: Afrika & 3,7 & 3,8 & 2,9 & 4,7 & 3,8 & 1,5 & 1,3 & 1,1 & 0,8 & 1,3 \\
\hline Amerika & 0,1 & 0,2 & 0,1 & 0,2 & 0,4 & 0,4 & 0,1 & 0,1 & 0,1 & 0,1 \\
\hline Asie & 9,5 & 11,4 & 33,2 & 26,2 & 30,2 & 29,3 & 40,6 & 40,2 & 39,2 & 47,9 \\
\hline Evropa & 86,5 & 84,1 & 62,4 & 66,9 & 64,0 & 67,9 & 57,3 & 57,7 & 59,2 & 49,2 \\
\hline Austrálie a Oceánie & 0,0 & 0,0 & 0,0 & & 0,0 & 0,0 & & 0,02 & 0,004 & \\
\hline Neurčeno & 0,2 & 0,4 & 1,5 & 1,9 & 1,6 & 0,9 & 0,7 & 0,9 & 0,7 & 1,5 \\
\hline
\end{tabular}




\section{Tabulka 9}

Nelegální migrace přes státní hranice České republiky - podle státní př́ílušnosti osob

\begin{tabular}{|c|c|c|c|c|c|c|c|c|c|c|}
\hline Rok & 1993 & 1994 & 1995 & 1996 & 1997 & 1998 & 1999 & 2000 & 2001 & 2002 \\
\hline $\begin{array}{l}\text { Nelegální migrace přes státní } \\
\text { hranice ČR-zjištěno osob }\end{array}$ & 43302 & 20480 & 19172 & 23705 & 29339 & 44672 & 32325 & 32720 & 23834 & 14741 \\
\hline z toho občané ČR & 1537 & 1648 & 2040 & 2526 & 2014 & 1715 & 1948 & 1959 & 2744 & 2109 \\
\hline Cizinci & 41765 & 18832 & 17132 & 21179 & 27325 & 42957 & 30377 & 30761 & 21090 & 12632 \\
\hline \multicolumn{11}{|l|}{ *nejvíce zastoupeni občané } \\
\hline Číny & 984 & 121 & 251 & 677 & 784 & 1055 & 984 & 926 & 512 & 2301 \\
\hline Indie & 412 & 163 & 612 & 362 & 550 & 1204 & 1613 & 2574 & 2706 & 1190 \\
\hline Vietnamu & 902 & 323 & 644 & 256 & 477 & 1264 & 893 & 1826 & 1300 & 1074 \\
\hline SRN & 419 & 534 & 701 & 652 & 1780 & 716 & 502 & 1052 & 1764 & 1022 \\
\hline Polska & 540 & 795 & 746 & 1227 & 1514 & 1011 & 1051 & 1604 & 1193 & 1019 \\
\hline Gruzie & 17 & 18 & 6 & 8 & 5 & 4 & 25 & 148 & 1118 & 895 \\
\hline Moldavska & 14 & 35 & 33 & 162 & 517 & 1105 & 1118 & 3010 & 1742 & 875 \\
\hline Ukrajiny & 191 & 382 & 574 & 746 & 842 & 985 & 1592 & 2265 & 758 & 559 \\
\hline Ruska & ** & 126 & 144 & 165 & 162 & 300 & 431 & 545 & 335 & 368 \\
\hline Bulharska & 4723 & 2380 & 2079 & 1936 & 1929 & 1691 & 1967 & 2323 & 669 & 294 \\
\hline Slovenska & 76 & 128 & 153 & 214 & 213 & 168 & 108 & 212 & 280 & 262 \\
\hline Rumunska & 4096 & 1299 & 1488 & 2378 & 3879 & 4372 & 5796 & 4281 & 3911 & 255 \\
\hline Iráku & 346 & 169 & 632 & 1372 & 2326 & 1587 & 829 & 327 & 418 & 228 \\
\hline Srbsko a Černá Hora & & 4529 & 1766 & 3202 & 3569 & 16052 & 2778 & 303 & 156 & 132 \\
\hline Turecka & 576 & 417 & 1740 & 1690 & 873 & 602 & 475 & 350 & 204 & 88 \\
\hline Srí Lanky & 208 & 240 & 938 & 110 & 419 & 917 & 1992 & 1833 & 272 & 76 \\
\hline Běloruska & ** & 32 & 30 & 27 & 62 & 94 & 121 & 176 & 106 & 68 \\
\hline Afghánistánu & 123 & 305 & 628 & 570 & 2311 & 4959 & 5242 & 3734 & 695 & 42 \\
\hline Údaje v \% cizinci & 100,0 & 100,0 & 100,0 & 100,0 & 100,0 & 100,0 & 100,0 & 100,0 & 100,0 & 100,0 \\
\hline Číny & 2,4 & 0,6 & 1,5 & 3,2 & 2,9 & 2,5 & 3,2 & 3,0 & 2,4 & 18,2 \\
\hline Indie & 1,0 & 0,9 & 3,57 & 1,71 & 2,01 & 2,80 & 5,3 & 8,4 & 12,8 & 9,4 \\
\hline Vietnamu & 2,2 & 1,7 & 3,8 & 1,2 & 1,7 & 2,9 & 2,9 & 5,9 & 6,2 & 8,5 \\
\hline SRN & 1,0 & 2,8 & 4,1 & 3,1 & 6,5 & 1,7 & 1,7 & 3,4 & 8,4 & 8,1 \\
\hline Polska & 1,3 & 4,2 & 4,4 & 5,8 & 5,5 & 2,4 & 3,5 & 5,2 & 5,7 & 8,1 \\
\hline Gruzie & 0,0 & 0,1 & 0,0 & 0,0 & 0,0 & 0,0 & 0,1 & 0,5 & 5,3 & 7,1 \\
\hline Moldavska & 0,0 & 0,2 & 0,2 & 0,8 & 1,9 & 2,6 & 3,7 & 9,8 & 8,3 & 6,9 \\
\hline Arménie & ** & 0,6 & 0,2 & 0,1 & 0,1 & 0,1 & 0,2 & 1,3 & 7,5 & 6,4 \\
\hline Ukrajiny & 0,5 & 2,0 & 3,4 & 3,5 & 3,1 & 2,3 & 5,2 & 7,4 & 3,6 & 4,4 \\
\hline Ruska & ** & 0,7 & 0,8 & 0,8 & 0,6 & 0,7 & 1,4 & 1,8 & 1,6 & 2,9 \\
\hline Bulharska & 11,3 & 12,6 & 12,1 & 9,1 & 7,1 & 3,9 & 6,5 & 7,6 & 3,2 & 2,3 \\
\hline Slovenska & 0,2 & 0,7 & 0,9 & 1,0 & 0,8 & 0,4 & 0,4 & 0,7 & 1,3 & 2,1 \\
\hline Rumunska & 9,8 & 6,9 & 8,7 & 11,2 & 14,2 & 10,2 & 19,1 & 13,9 & 18,5 & 2,0 \\
\hline Iráku & 0,8 & 0,9 & 3,7 & 6,5 & 8,5 & 3,7 & 2,7 & 1,1 & 2,0 & 1,8 \\
\hline Srbska a Černé Hory & 0,0 & 24,1 & 10,3 & 15,1 & 13,1 & 37,4 & 9,2 & 1,0 & 0,7 & 1,0 \\
\hline Turecka & 1,4 & 2,21 & 10,16 & 8,0 & 3,19 & 1,4 & 1,56 & 1,1 & 1,0 & 0,7 \\
\hline Srí Lanky & 0,5 & 1,3 & 5,5 & 0,5 & 1,5 & 2,1 & 6,6 & 6,0 & 1,3 & 0,6 \\
\hline Běloruska & ** & 0,2 & 0,2 & 0,1 & 0,2 & 0,2 & 0,4 & 0,6 & 0,5 & 0,5 \\
\hline Afghánistánu & 0,7 & 1,6 & 3,7 & 2,7 & 8,5 & 11,5 & 17,3 & 12,1 & 3,3 & 0,3 \\
\hline
\end{tabular}

** v roce 1993 nerozlišovány nástupnické státy

* řazeno podle nejvyšší hodnoty aktuálního období 


\section{Tabulka 10}

Nelegální migrace přes státní hranice České republiky - způsob vstupu migrantů na území ČR před nelegálním překročením státních hranic ČR ve směru z ČR - porovnání shodného období

\begin{tabular}{|c|c|c|c|c|c|c|c|c|}
\hline \multirow{2}{*}{$\begin{array}{l}\text { Období } \\
\text { Roku }\end{array}$} & \multirow{2}{*}{$\begin{array}{c}1.1 .-31.12 \\
2001\end{array}$} & \multirow[b]{2}{*}{$\mathrm{tj} . \%$} & \multirow[b]{2}{*}{ tj.\% } & \multirow{2}{*}{$\begin{array}{c}1.1 .-31.12 \\
2002\end{array}$} & \multirow[b]{2}{*}{ tj.\% } & \multirow[b]{2}{*}{ tj.\% } & \multicolumn{2}{|c|}{ Změna oproti předchozímu období } \\
\hline & & & & & & & v [ \%] & absolutní číslo \\
\hline $\begin{array}{l}\text { Nelegální migrace přes státní hranice ČR } \\
- \text { - zjištěno osob } \\
\end{array}$ & 23834 & & & 14741 & & & $-38,2$ & -9093 \\
\hline z toho cizinců & 21090 & 100,0 & & 12632 & 100,0 & & $-40,1$ & -8458 \\
\hline Cizinci ve směru z ČR & 16276 & 77,2 & & 8496 & 67,3 & & $-47,8$ & -7780 \\
\hline $\begin{array}{c}\text { z toho pouze cizinci ve směru z C CR } \\
\text { (mínus cizinci s pobytem na vízum nad } \\
90 \text { dní, s trvalým pobytem v ČR a } \\
\text { žadatelé o azyl v ČR) }\end{array}$ & 10378 & 49,2 & 100,0 & 5732 & 45,4 & 100,0 & $-44,8$ & -4646 \\
\hline z toho A. vstup nelegální & 1292 & 100,0 & 12,4 & 1165 & 100,0 & 20,3 & $-9,8$ & -127 \\
\hline Ve směru & 384 & 29,7 & & 347 & 29,8 & & $-9,6$ & -37 \\
\hline ze SRN & 185 & 14,3 & & 22 & 1,9 & & $-88,1$ & -163 \\
\hline z Rakouska & 6 & 0,5 & & 12 & 1,0 & & 100,0 & 6 \\
\hline ze Slovenska & 140 & 10,8 & & 221 & 19,0 & & 57,9 & 81 \\
\hline letecky & 7 & 0,5 & & 10 & 0,9 & & 42,9 & 3 \\
\hline neurčen & 570 & 44,1 & & 553 & 47,5 & & $-3,0$ & -17 \\
\hline B. vstup legální & 4503 & 100,0 & 43,4 & 1618 & 100,0 & 28,2 & $-64,1$ & -2885 \\
\hline Ve směru & 525 & 11,7 & & 354 & 21,9 & & $-32,6$ & -171 \\
\hline ze SRN & 13 & 0,3 & & 19 & 1,2 & & 46,2 & 6 \\
\hline z Rakouska & 15 & 0,3 & & 37 & 2,3 & & 146,7 & 22 \\
\hline ze Slovenska & 2509 & 55,7 & & 367 & 22,7 & & $-85,4$ & -2142 \\
\hline letecky & 1001 & 22,2 & & 659 & 40,7 & & $-34,2$ & -342 \\
\hline neurčen & 440 & 9,8 & & 182 & 11,2 & & $-58,6$ & -258 \\
\hline C. vstup nezjištěn, neuveden & 4583 & 100,0 & 44,2 & 2949 & 100,0 & 51,4 & $-35,7$ & -1634 \\
\hline Ve směru & 29 & 0,6 & & 2 & 0,1 & & $-93,1$ & -27 \\
\hline ze SRN & 19 & 0,4 & & & & & $-100,0$ & -19 \\
\hline z Rakouska & 1 & 0,02 & & & & & $-100,0$ & -1 \\
\hline ze Slovenska & 54 & 1,2 & & 20 & 0,7 & & $-63,0$ & -34 \\
\hline letecky & 90 & 2,0 & & 2 & 0,1 & & $-97,8$ & -88 \\
\hline neurčen & 4390 & 95,8 & & 2925 & 99,2 & & $-33,4$ & -1465 \\
\hline $\begin{array}{c}\text { A+B (způsob vstupu nelegálních } \\
\text { migrantů zjištěn) }\end{array}$ & 5795 & 100,0 & 55,8 & 2783 & 100,0 & 48,6 & $-52,0$ & -3012 \\
\hline Z toho: vstup nelegální & 1292 & 22,3 & & 1165 & 41,9 & & $-9,8$ & -127 \\
\hline Legální & 4503 & 77,7 & & 1618 & 58,1 & & $-64,1$ & -2885 \\
\hline C. vstup nezjištěn, neuveden & 4583 & 100,0 & 44,2 & 2949 & 100,0 & 51,4 & $-35,7$ & -1634 \\
\hline
\end{tabular}

